\title{
Agenda suprema \\ Interesses em disputa no controle de constitucionalidade das leis no Brasil ${ }^{1}$
}

Fabiana Luci Oliveira

Introdução

O papel desempenhado pelo poder Judiciário no processo político e os impactos da atuação dos tribunais na formulação e na implementação de políticas públicas são temáticas centrais nas ciências sociais hoje. Fala-se do Judiciário em seu papel clássico de contrapeso aos poderes Executivo e Legislativo, de sua função contramajoritária, permitindo que minorias sejam incorporadas ao processo político, e como lembram Kapiszewski e Taylor (2008, p. 743), retomando documento do Banco Interamericano de Desenvolvimento acerca dos judiciários latino-americanos, de quatro papéis-chave: jogador de veto, ator político, árbitro imparcial e representante da sociedade.

A importância política do Judiciário e suas contribuições para a boa governança têm sido reconhecidas a partir do desempenho desses diferentes papéis. Mas que tipo de interesses têm sido arbitrados nos tribunais, e que vozes se fazem ouvir no processo político por meio desse ator?

Partindo dessas perguntas descritivas e tendo como objeto o Supremo Tribunal Federal (STF), discutimos a formação de sua agenda decisória, observando com detalhe e de forma sistemática sobre o que o STF decidiu no controle concentrado de constitucionalidade das leis e qual o alcance dessas decisões.

1. Este artigo é resultado de pesquisa com suporte financeiro da Fapesp 
A compreensão da agenda decisória do STF permite melhor precisar o fenômeno de expansão do poder Judiciário no Brasil e o aumento da sua influência política, ajudando a problematizar uma série de indagações postas acerca dos efeitos dessa expansão. Seguindo a linha discutida pela literatura contemporânea sobre judiciário e política no Brasil, identificamos quatro questões centrais:

- Qual o conteúdo da agenda decisória do STF, ou seja, quais interesses são arbitrados no tribunal no âmbito da Ação Direta de Inconstitucionalidade (ADI)?

- Até que ponto as decisões do STF interferem na implementação de políticas públicas, ou seja, qual o alcance de suas decisões?

- O sTF tem possibilitado a incorporação de vozes minoritárias no processo político, isto é, atua como instituição contramajoritária?

- O Supremo pode ser considerado instância de implementação de direitos sociais e coletivos, ou seja, o tribunal tem contribuído para uma maior efetividade de direitos e para o fortalecimento da democracia no país?

São essas as questões norteadoras deste artigo, ao que é imperativo fazer duas ressalvas. A primeira é que não há resposta única para essas perguntas, pois dependendo do recorte de dados privilegiado na análise as respostas podem ser bem diferentes e até mesmo contraditórias. A segunda é que não temos respostas definitivas ou exaustivas, mas trazemos evidências de pesquisa que respondem a primeira delas e elementos que contribuem com o debate corrente em relação às outras três, no sentido de identificar os papéis que o Supremo desempenha ao arbitrar interesses em disputa no controle de constitucionalidade das leis via ADI.

Para contextualizar a discussão, a década de 1980 pode ser considerada marco inaugural do fenômeno de expansão do poder Judiciário em escala global, quando os tribunais começaram a despontar como os "principais tradutores de dispositivos constitucionais em parâmetros para a vida pública”, nas palavras de Hirschl (2013, p. 361), o que se deu em decorrência de processos de constitucionalização por que passaram vários países. O autor calcula pelo menos 150 países, da África do Sul, América Latina, a países da União Europeia, cobrindo cerca de três quartos da população mundial.

No Brasil, esse processo de expansão acirra-se na década de 1990, quando, como diversos autores apontam ${ }^{2}$, assuntos cruciais de natureza política, moral, social e

2. Entre os principais trabalhos estão os de Arantes (1997), Castro (1997), Vieira (1994; 2008), Werneck Vianna et al. (1999; 2007), Maciel e Koerner (2002), Carvalho (2004; 2009), Taylor (2007), 
econômica passaram a ser cada vez mais decididos pelos tribunais, especialmente por sua instância máxima, o Supremo Tribunal Federal, composto por onze juízes não eleitos.

Se, por um lado, a expansão do poder político dos tribunais gera uma preocupação com a transferência de poder das instituições representativas para as judiciárias (ou seja, um problema de legitimidade decisória, uma vez que os tribunais não seriam responsáveis - accountable - perante os cidadãos), por outro, suscita a possibilidade de que haja um maior equilíbrio das forças em disputa, pois na medida em que atuaria como um poder contramajoritário, o Judiciário refrearia as maiorias políticas contingentes.

O protagonismo do poder Judiciário é denominado juristocracia por Hirschl (2007), mas os principais conceitos mobilizados no debate são os de judicialização da política e ativismo judicial.

O conceito de judicialização da política é largamente utilizado e ganhou diferentes contornos, referindo-se a aspectos tão diversificados da participação do Judiciário na política, que se questiona sua validade teórica (Koerner et al., 2011; Koerner, 2013), e o mesmo se aplica ao ativismo judicial. Há uma disputa de significados e contestações sobre a possibilidade de generalização desses conceitos.

A generalização do conceito de judicialização é difícil, porque a atuação política do Judiciário e da Suprema Corte em qualquer país varia de acordo com pelo menos quatro aspectos: (1) o desenho institucional, ou seja, as ferramentas que possibilitam ao Judiciário ter impacto nas decisões políticas e aos juízes exercerem um papel político; (2) as forças sociais em disputa e os usos que se faz do tribunal; (3) a dinâmica interna do tribunal, influenciada pela ideologia política e filosofia judicial dos juízes; e (4) a reação da opinião pública e dos demais poderes às decisões do tribunal (compliance).

Ainda que seja difícil precisar o conceito de judicialização da política, há alguns indicadores que ajudam a situar o fenômeno do qual estamos falando. Olhando para o Brasil, embora a definição mais citada nos artigos indexados na biblioteca Scielo $^{3}$, a partir dos termos "judicialização da política" e "ativismo judicial”, seja a de

V. Oliveira (2005), Wang (2009), Sadek (2011), F. Oliveira (2011; 2013) e Engelmann e Cunha Filho (2013).

3. Um rápido levantamento feito em 5/12/2014 (http://www.scielo.br/cgi-bin/wxis.exe/iah/?Isis Script $=\mathrm{iah} / \mathrm{iah} . \mathrm{xis} \&$ base $=$ article $\% 5$ Edlibrary\&index $=\mathrm{kw} \& \mathrm{fmt}=\mathrm{iso} . \mathrm{pft} \&$ lang $=\mathrm{p} ）$ localizou treze artigos indexados com o termo "judicialização da política" e 21 com o termo "ativismo judicial", totalizando 28 artigos excluindo-se as sobreposições. Nessa amostra de 28 artigos, 23 fazem menção indireta à definição de Tate, por meio da citação de Werneck Vianna et al. (1999), e onze artigos citam diretamente Tate (1995). Apenas dois artigos trazem Hirschl (2007) como referência e um, Domingo (2004). 
Vallinder (1995), na elaboração de Tate (1995), outra definição bastante apropriada é a de Domingo (2004; 2010).

São três os principais indicadores do fenômeno da judicialização da política na elaboração da autora: o aumento na incidência de decisões judiciais sobre processos sociais e sobre processos e conflitos políticos, assim como o crescimento do uso dos tribunais como lócus de mobilização da sociedade civil organizada em torno de demandas e interesses sociais e econômicos.

Mas em que medida o maior protagonismo político do Judiciário concorreria para o fortalecimento e o aprofundamento da democracia? Buscamos contribuir para esse debate discutindo os papéis que o Supremo Tribunal Federal tem desempenhado na vida social e política do país, observando suas decisões na esfera do controle concentrado de constitucionalidade via ADI, entre os anos de 1988 e 2014.

Considerando os dois primeiros indicadores utilizados por Domingo (2004) em sua definição de judicialização (o aumento da incidência de decisões judiciais sobre processos sociais e políticos), vemos no Brasil um grande volume de ações judiciais se repetindo a cada ano em todas as instâncias da Justiça. Olhando só para o STF, no ano de 2013 ingressaram no tribunal 72.083 casos novos, e em 2014 foram 78.110.

Falcão et al. (2011) calculam que em pouco mais de vinte anos (de 1988 a 2009), o Supremo proferiu cerca de 1,3 milhão de decisões, sendo $91 \%$ desse montante em sede recursal.

Os próprios ministros reconhecem o excesso de ações. Em palestra proferida na Associação dos Advogados de São Paulo, o ministro Luís Roberto Barroso, por exemplo, afirmou que "a maior parte dos recursos humanos e materiais de cada gabinete acaba sendo consumida para lidar com um imenso varejo de miudezas, sem qualquer repercussão geral. Processos que deveriam transitar em julgado após o pronunciamento da segunda instância” (Macedo, 2014).

O ministro Barroso fazia referência aos recursos extraordinários e agravos de instrumento, mas quando olhamos para casos mais complexos de exame da compatibilidade entre lei e Constituição, que correspondem a menos de $1 \%$ do volume de ações que o tribunal recebe ${ }^{4}$, temos um total de 4.896 ADIs impetradas no período de outubro de 1988 a julho de 2014. Desse total, 51\% já tinham decisão do mérito, 16\% decisão liminar e 33\% aguardavam julgamento.

4. De acordo com levantamento de Falcão et al. (2011, p. 301), de 1988 a 2011 as três classes processuais de maior volume no STF foram os agravos de instrumento, que correspondiam a 53,06\% do total de processos recebidos pelo tribunal; os recursos extraordinários, a 37,66\%, e os habeas corpus, $2,97 \%$. As ADIs ficavam em $11^{\circ}$ lugar, correspondendo a $0,34 \%$ do total de processos recebidos pelo STF no período em questão. 
São 2.712 ações julgadas em definitivo que analisamos para responder sobre o que exatamente o Supremo tem privilegiado decidir no controle de constitucionalidade das leis via ADI'

\section{A agenda decisória do STF no âmbito da ADI}

Quando se fala em controle de constitucionalidade das leis no Brasil, um dos estudos empíricos basilares é o de Werneck Vianna et al. (1999), juntamente com a posterior atualização da pesquisa (Werneck Vianna et al., 2007). Os autores dedicaram-se a sistematizar a entrada das ADIs no STF e desenharam o padrão de judicialização dos conflitos a partir da identificação dos temas e dos atores envolvidos nas ações, mas não detalharam nem seus assuntos específicos nem o padrão decisório do Supremo ou o alcance das decisões.

Uma das principais constatações desses estudos diz respeito à área privilegiada de acionamento do Supremo via ADI, sendo a administração pública o tema predominante entre os anos de 1988 e 2005. Segundo os autores, uma vez que mais da metade das ADIs que ingressaram no tribunal tratam da administração pública, o Supremo estaria numa posição próxima a de um conselho de Estado:

Como escoadouro de conflitos entre sociedade e Estado, dos que nascem no próprio interior da administração pública e da federação, e instrumento de trabalhadores e empresários, elas fazem com que o país, sob a forma como se apresenta hoje, não seja mais governável sem elas. Aqui, além de ser instrumento da defesa de minorias, sua origem constitucional clássica, a Adin também é recurso institucional estratégico de governo, instituindo, na prática, o Supremo Tribunal Federal como um conselho de Estado do tipo prevalecente em países de configuração unitária. A distribuição das Adins por classe temática atesta esse fato em todas as suas cores: em dezessete anos, foi ajuizado um total de $2.178 \mathrm{em}$ matéria de administração pública, $60 \%$ do total, sintoma evidente dos efeitos de recepção por parte do nosso direito constitucional do direito administrativo (Werneck Vianna et al., 2007, pp. 43-44).

5. Essas 2.712 ações correspondem à totalidade das ADIs localizadas com algum tipo de decisão final no período (por decisão final entenda-se as ADIs com julgamento do mérito e as decididas monocraticamente pelo relator, ainda que em liminar, mas sem interposição de recurso, uma vez decorrido o prazo. Essas decisões em geral são no sentido de negar seguimento, extinguir ou arquivar o processo. É importante frisar que o critério de consistência utilizado foi a verificação de que as ADIs incluídas nessa lista se encontravam baixadas ao arquivo do STF, portanto não se encontram mais em andamento). Embora o recorte temporal de busca tenha se iniciado em 1988, a partir da data de ingresso da primeira ADI no STF, somente em 1989 encontramos a primeira decisão. 
Apesar do detalhamento do estudo, não temos muita informação sobre o que exatamente na administração pública é mais judicializado nem sobre o que o STF tem privilegiado decidir. Assim, temos uma ideia geral dos temas de maior peso no ingresso das ações, mas pouca informação sobre a agenda de assuntos específicos decididos no STF.

Sabemos que a formação da agenda do Supremo não é totalmente controlada pelo tribunal, pois ele é um ator reativo, que depende das demandas levadas a ele pelos atores legitimados. Mas o STF tem poder de agenda ao escolher o que leva a plenário, e quando leva. E ainda, cada ministro tem prerrogativa para decidir em determinadas situações de forma monocrática, no prazo de sua escolha. A lei 9.868/99 prevê em seu artigo quarto que "a petição inicial inepta, não fundamentada e a manifestamente improcedente serão liminarmente indeferidas pelo relator", cabendo agravo neste caso. Note-se que a maioria dessas decisões não tem interposição de recursos, sendo tomadas como decisões finais, e por isso são analisadas aqui.

Nem a Constituição nem a lei 9.868/99 nem o regimento interno do Supremo estabelecem prazos ou ordem para o tribunal decidir: a escolha do que será levado a plenário é primeiro do relator da ação e depois da presidência do STF. A escolha da pauta, como se observa ao longo da troca de presidências do tribunal, é feita conforme critérios pessoais dos presidentes, de acordo com o que decidem priorizar em sua gestão (Falcão e Oliveira, 2013).

Há muita especulação na mídia, mas poucos estudos têm se dedicado a enfrentar esse desafio. Destacamos aqui dois trabalhos que explicitamente se propuseram a discutir a agenda do Supremo. O primeiro, coordenado por Sundfeld (Sundfeld et al., 2010), analisa 1.335 ações (ADIs, ADCs e ADPFs) que ingressaram no Supremo de 1988 a julho de 2010, questionando diplomas do Executivo e do Legislativo federais. O trabalho avança no detalhamento das temáticas julgadas, identificando como mais recorrentes aquelas relativas à seguridade social, às políticas econômicas e tributárias, ao funcionalismo público e ao funcionamento dos partidos políticos e eleições.

Em termos do alcance das decisões, os autores afirmam que o Supremo pouco decide o mérito das questões levadas até ele, uma vez que mais da metade das ações ou perderam o objeto ou foram descartadas por ilegitimidade ativa dos proponentes. Assim, concluem que o STF foi "pouco interventivo" nas ações dos poderes Executivo e Legislativo federais.

O segundo trabalho que se propõe a estudar a agenda do STF é o de E. Oliveira (2013), que analisa as decisões do Supremo que ganharam maior repercussão na mídia, a partir da análise dos jornais Folha de S. Paulo, Correio Braziliense, Correio do Povo e Estado de Minas, entre os anos de 1995 e 2011 . O autor busca identificar qual o conteúdo da agenda do STF e como esta agenda é construída. 
As notícias são classificadas por Oliveira em cinco categorias: econômica, social, meio ambiente, política criminal e cultura, a partir da organização de uma lista de assuntos que apareceram em cada um desses âmbitos, mas sem quantificar sua incidência ${ }^{6}$. O autor argumenta que o Supremo "opera, funcionalmente, como órgão de governo" (Idem, p. 224) e fundamenta seu argumento pela constatação de que a agenda do STF é política, tanto em seu conteúdo quanto nos atores que a constroem, uma vez que, com base nas estatísticas do tribunal, se constata que quem mais aciona o STF via ADI são os agentes políticos.

O presente artigo dialoga com esses dois trabalhos, mas se diferencia deles não só em termos das questões norteadoras, mas principalmente pela seleção dos dados - como já dito, utilizamos aqui ADIs julgadas pelo Supremo desde 1988 até julho de 2014, incluindo todas as ações para as quais o STF tenha proferido algum tipo de decisão final, ainda que a decisão tenha sido "não decidir", ou seja, não conhecendo da ação, extinguindo-a ou julgando-a prejudicada.

Observando a totalidade das ADIs julgadas entre 1988 e julho de 2014, vemos que o tema ${ }^{7}$ sobre qual o STF mais decidiu por meio desse instrumento é "agentes públicos". Essa categoria reúne os assuntos relativos ao funcionalismo público, seja a criação seja a organização de carreiras, a regulamentação de concursos públicos, a remuneração e demais prerrogativas dos cargos públicos, além de incorporar aspectos ligados aos crimes de responsabilidade de servidores e a discussão da isonomia entre as carreiras. Isto é, o funcionalismo público domina $40 \%$ da pauta do STF em controle concentrado de constitucionalidade (Gráfico 1).

A segunda categoria temática mais frequente é "administração pública”, correspondendo a $15 \%$ do total de ações julgadas, referindo-se às finanças públicas, à política orçamentária, ao processo legislativo, à criação e delimitação de municípios, às licitações e concessões de serviços públicos e à separação de poderes.

6. Por exemplo, como vemos na página 226, o autor lista alguns dos assuntos classificados na temática social: racionamento de energia elétrica, correção do FGTS, auxílio-moradia para juízes etc.

7. As categorias temáticas foram construídas com base na petição inicial, considerando a área temática a qual o conteúdo do diploma questionado tocava, e não a área do direito, conforme classificação do próprio tribunal. Por exemplo, no caso da ADI 251, o STF apresenta a seguinte classificação: "direito administrativo e outras matérias de direito público”. Mas quando acessamos a petição inicial, vemos que os diplomas questionados tratam da organização judiciária do estado do Ceará e das competências dos tribunais; assim, nossa classificação adotada é “administração da justiça”. É importante frisar que na maioria dos casos as normas questionadas são referentes a um único tema, mas em algumas ADIs, sobretudo quando se trata do questionamento de constituições estaduais, há uma série de artigos questionados ao mesmo tempo e com diversidade de temáticas. Nesses casos, a opção foi por classificar o tema predominante, ou seja, a partir da contabilização dos temas em cada um dos artigos questionados, a ADI foi classificada na categoria temática que apresentava maior expressividade numérica. 
Em terceiro lugar, está a categoria "sociedade civil”, com 14\% das ações julgadas. Reúne os assuntos de maior impacto na sociedade civil, referentes à agenda de direitos civis, sociais e coletivos (como direitos do consumidor e meio ambiente), incorporando também assuntos ligados à regulamentação das profissões liberais e às normas de trânsito.

A baixa frequência da categoria "sociedade civil" é preocupante, sobretudo quando vemos que tem representatividade inferior às categorias "política tributária" e "regulação da economia” juntas, só não ficando abaixo da regulação da competição política e da administração da justiça.

GRÁFICO 1

Temas das ADIs
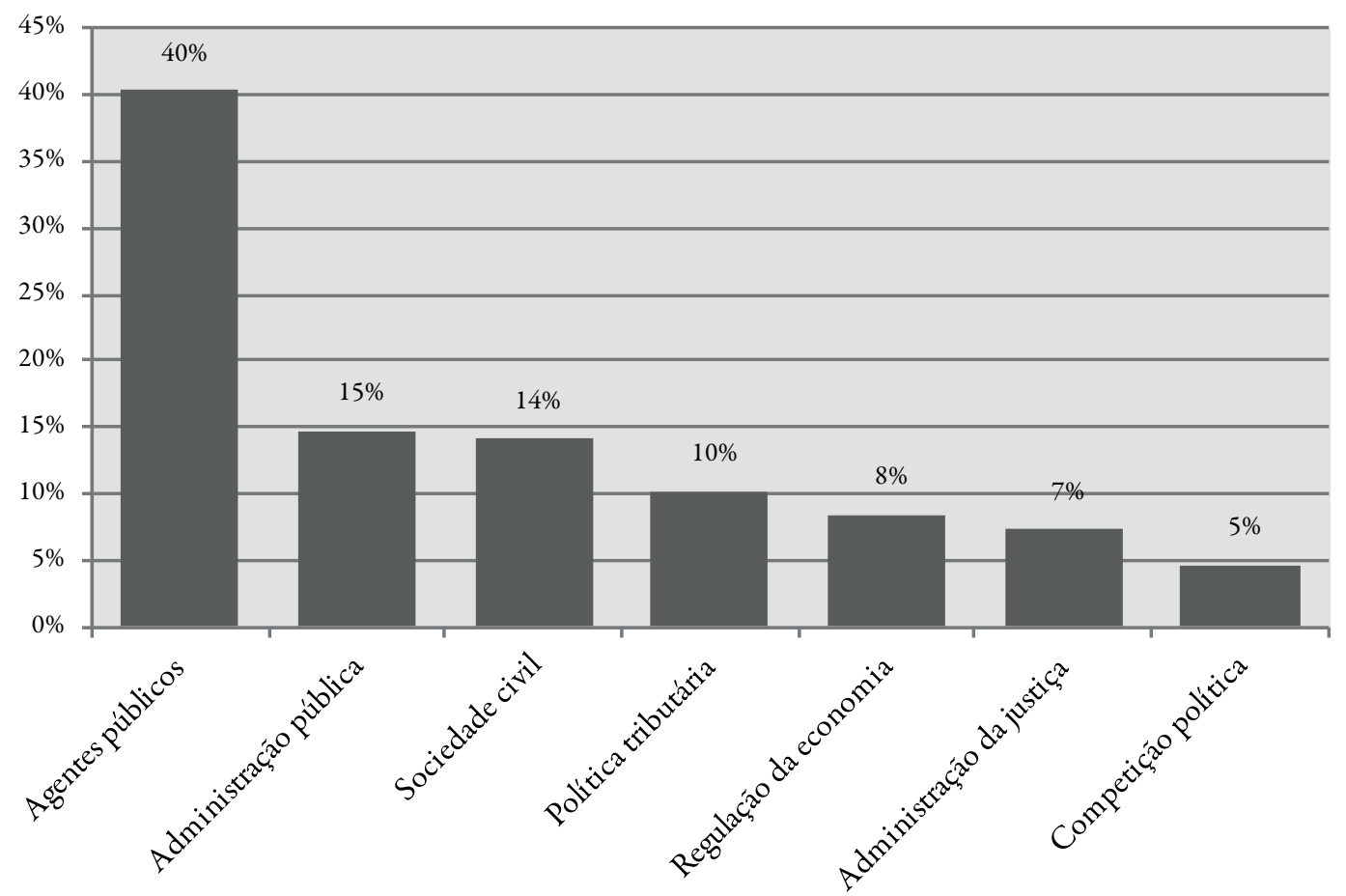

Base: 2.712 ADIs com decisão final, julgadas de outubro de 1988 a julho de 2014.

Nos gráficos 2 a 4 são detalhados os assuntos e sua frequência dentro de cada temática ${ }^{8}$. Começando pela mais frequente, os agentes públicos foram divididos em

8. As categorias de assunto no interior da temática foram construídas com base na petição inicial, considerando o sentido do pedido apresentado no relatório da ADI, ou seja, o sentido do questionamento da norma realizado pelo autor da ação, levando em conta o que visava o pedido. Assim como no caso do tema, adotamos o mesmo procedimento de atribuição de assunto quando os diplomas apresentavam diversidade, considerando aquele com maior expressividade numérica. 
quatro tipos: agentes políticos, militares, da justiça e demais servidores. $\mathrm{O}$ assunto mais frequente no tema é remuneração, aposentadoria e férias dos (demais) servidores públicos, seguido das prerrogativas dos servidores da justiça.

O STF, portanto, tem sido palco de disputas envolvendo benefícios e prerrogativas da burocracia estatal, com ênfase nas carreiras do sistema de justiça, nas quais se inclui o próprio Supremo. Ou seja, o tribunal dedica boa parte do seu tempo atuando como um setor de recursos humanos, ao arbitrar interesses de agentes públicos em conflito e colocar-se na posição de decidir pela ampliação ou redução de benefícios aos servidores (Gráfico 2).

GRÁFICO 2

Assuntos das ADIs, de acordo com temática

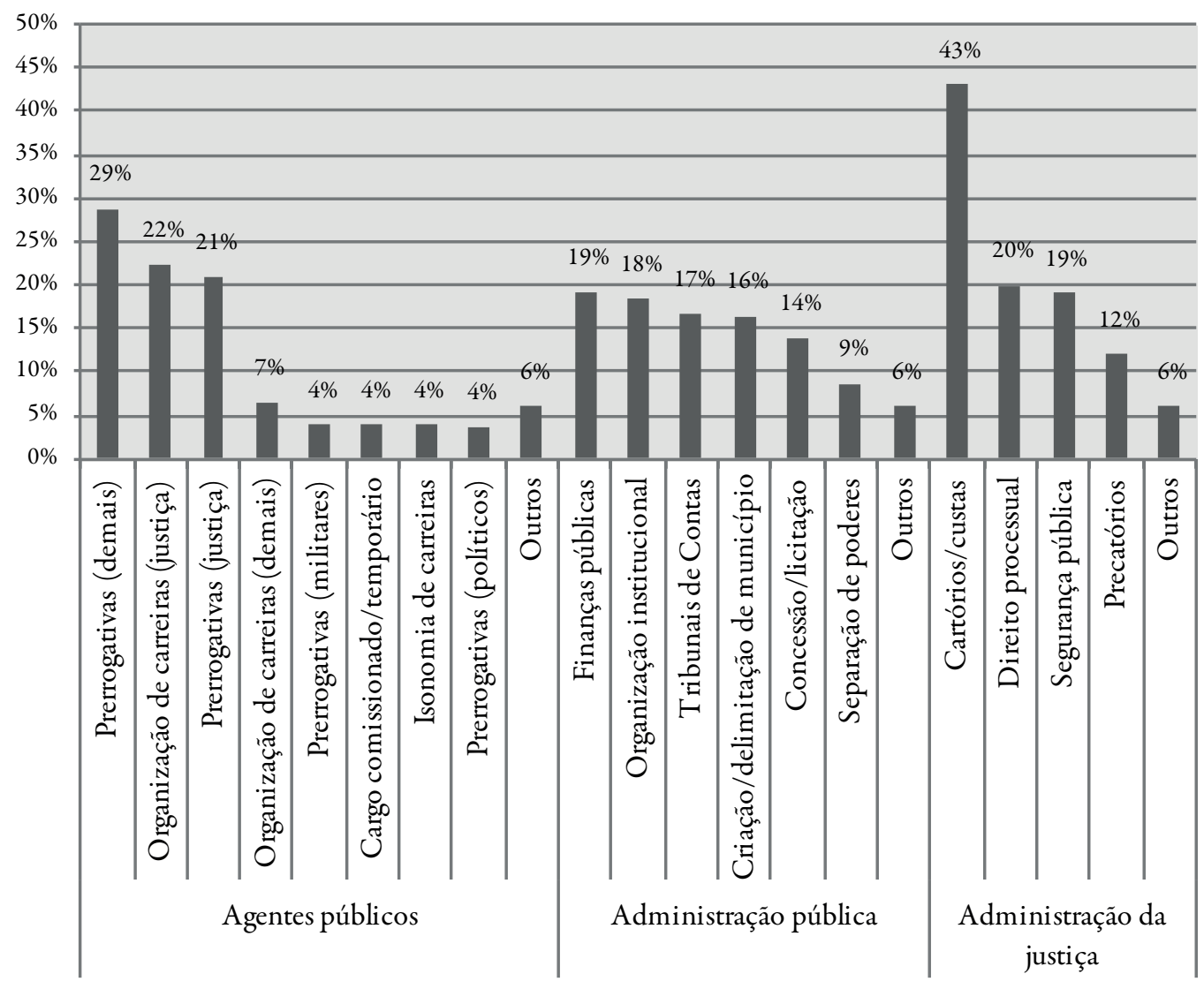

Base: ADIs com decisão final, julgadas de outubro de 1988 a julho de 2014: agentes públicos, 1.093; administração pública, 401; administração da justiça, 200.

Assim, a agenda do Supremo em controle de constitucionalidade foi tomada por uma pauta ligada ao delineamento das carreiras públicas. No âmbito da ADI, o tribunal tem se tornado uma espécie de divisão de recursos humanos. 
Levando em conta que o assunto "isonomia entre carreiras" na maioria das vezes refere-se às próprias carreiras jurídicas, como Ministério Público, Judiciário e Defensoria Pública, e que em outros assuntos também se encontram alguns que tocam na regulação de carreiras da justiça, constatamos que pelo menos metade do que o tribunal discute em termos de funcionalismo público refere-se às carreiras da justiça.

E considerando que a categoria temática "administração da justiça" (que trata da organização dos serviços da justiça, incluindo cartórios, taxas judiciárias, emolumentos, questões de direito processual e segurança pública, no que se refere ao funcionamento da polícia civil) tem $7 \%$ de ocorrência, podemos afirmar que parte considerável do tempo do STF em controle concentrado de constitucionalidade via ADI é gasto com assuntos pertinentes ao funcionamento do próprio sistema estatal de justiça.

O que ajuda a explicar o funcionalismo público ser a temática mais judicializada? Retomando Taylor (2008), sabemos que dois fatores determinam as chances de judicialização de uma política: os custos e os benefícios da política em questão (sendo que, quanto mais concentrados são os custos e mais difusos os benefícios, maiores são as chances de judicialização) e as características institucionais do Judiciário (influenciando a estratégia política, ou seja, a maneira pela qual as cortes serão utilizadas). Acrescentaríamos a esses dois fatores o conhecimento e a familiaridade com tais características institucionais - ou seja, uma vez que os servidores públicos ligados às carreiras jurídicas teriam maior familiaridade e conhecimento dos mecanismos institucionais judiciais, eles tenderiam a se utilizar mais desses mecanismos em suas demandas.

Joaquim Falcão (2014) atribui a grande expressividade do tema servidores públicos no Supremo ao sucesso do lobby da burocracia estatal na constituinte, indicando que o termo "servidor público" aparece 56 vezes na Constituição de 1988, ante as 24 vezes em que aparece a palavra "trabalhador", por exemplo. Além disso, traz dados de outros países - na constituição alemã, "servidor público” tem treze menções; na portuguesa, oito e na argentina, apenas uma. Segundo Falcão, isso "reflete a moldura institucional de nossa nação. $\mathrm{O}$ estamento burocrático, mais do que a sociedade, no controle do poder do Estado".

Em termos de regulação da economia, o assunto mais recorrente é a regulação do mercado (permissão para plantio, fabricação, comercialização de determinados produtos, assim como a venda de serviços), seguido da privatização. Na temática tributária, quase metade dos casos trata do ICMS, e depois há uma pulverização de ações referentes à normatização de alíquotas de outros impostos, assim como a concessão de incentivos fiscais (Gráfico 3).

Os assuntos classificados na categoria "sociedade civil" tratam de direitos civis, sociais e coletivos, assim como da regulação das relações entre particulares, como 
GRÁFICO 3

Assuntos das ADIs, de acordo com temática

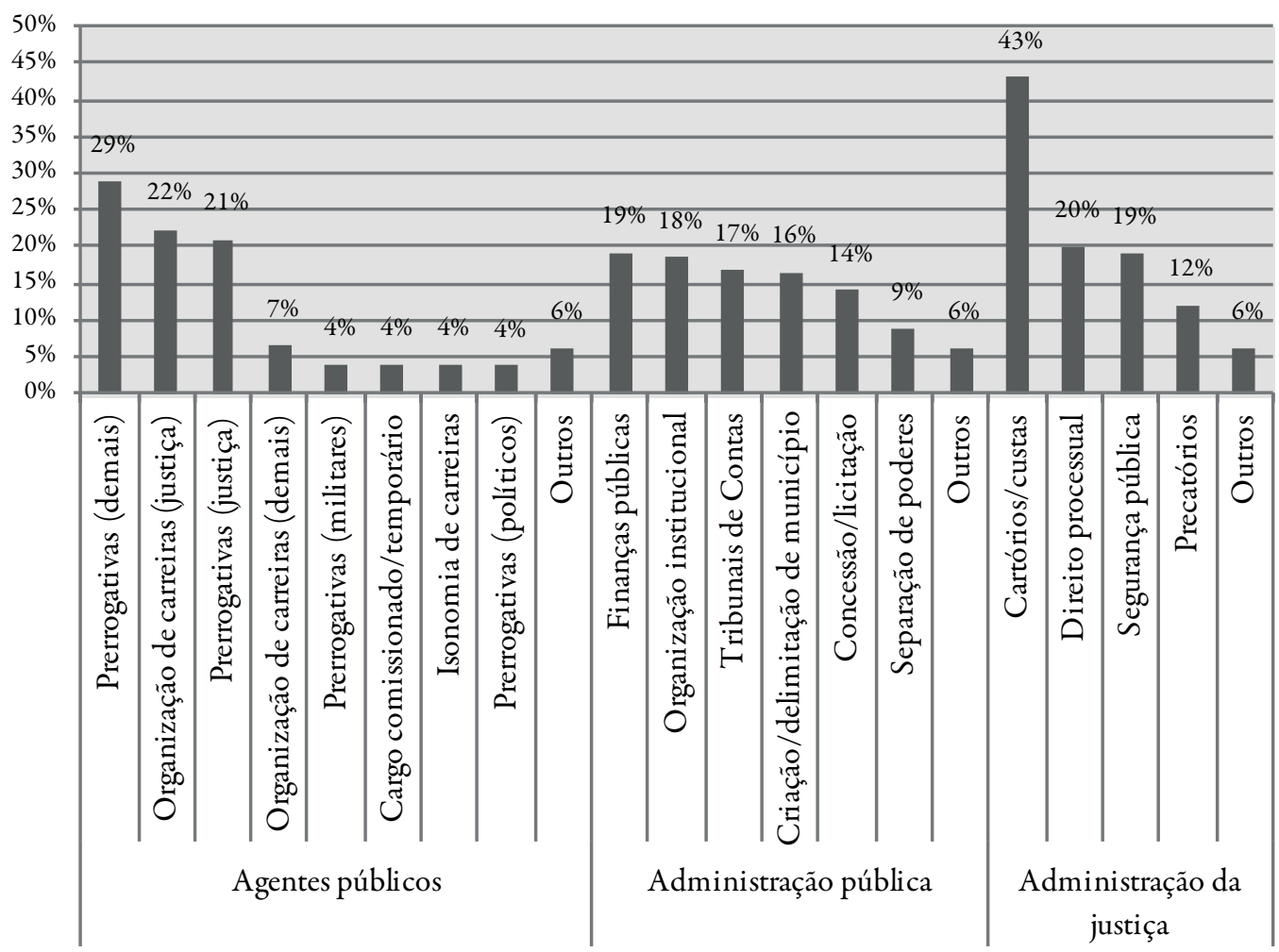

Base: ADIs com decisão final, julgadas de outubro de 1988 a julho de 2014: regulação da economia, 229; política tributária, 277.

cobrança de mensalidade escolar e regulamentação de corporações profissionais. Praticamente metade das ações nessa temática traz assuntos relativos aos direitos sociais, sobretudo direitos trabalhistas. Em segundo lugar, com 13\% do total das ações na temática, estão os direitos civis, em especial a liberdade de expressão (Gráfico 4).

Por outro lado, a categoria temática menos frequente, “competição política”, trata da regulação das eleições e do funcionamento dos partidos políticos, além de incorporar as discussões sobre duração de mandato, impeachment e inelegibilidade. Nota-se aqui muitas ações referentes à simulação de voto em urnas eletrônicas durante campanha eleitoral, que devido à sua expressividade foram contabilizadas em separado.

Somando os assuntos ligados aos agentes públicos, à administração pública e à administração da justiça, temos que $62 \%$ de tudo o que o STF decidiu no controle de constitucionalidade via $\mathrm{ADI}$ foi referente à organização do Estado, especialmente às carreiras de seus agentes e servidores. É a burocracia pública, com destaque para as carreiras da justiça, que tem controlado a pauta do Supremo. Seja para reduzir benefícios seja para ampliá-los, o fato é que o funcionalismo público tem sido a temática mais recorrente na agenda de quase todos os atores que acionam o tribunal. 


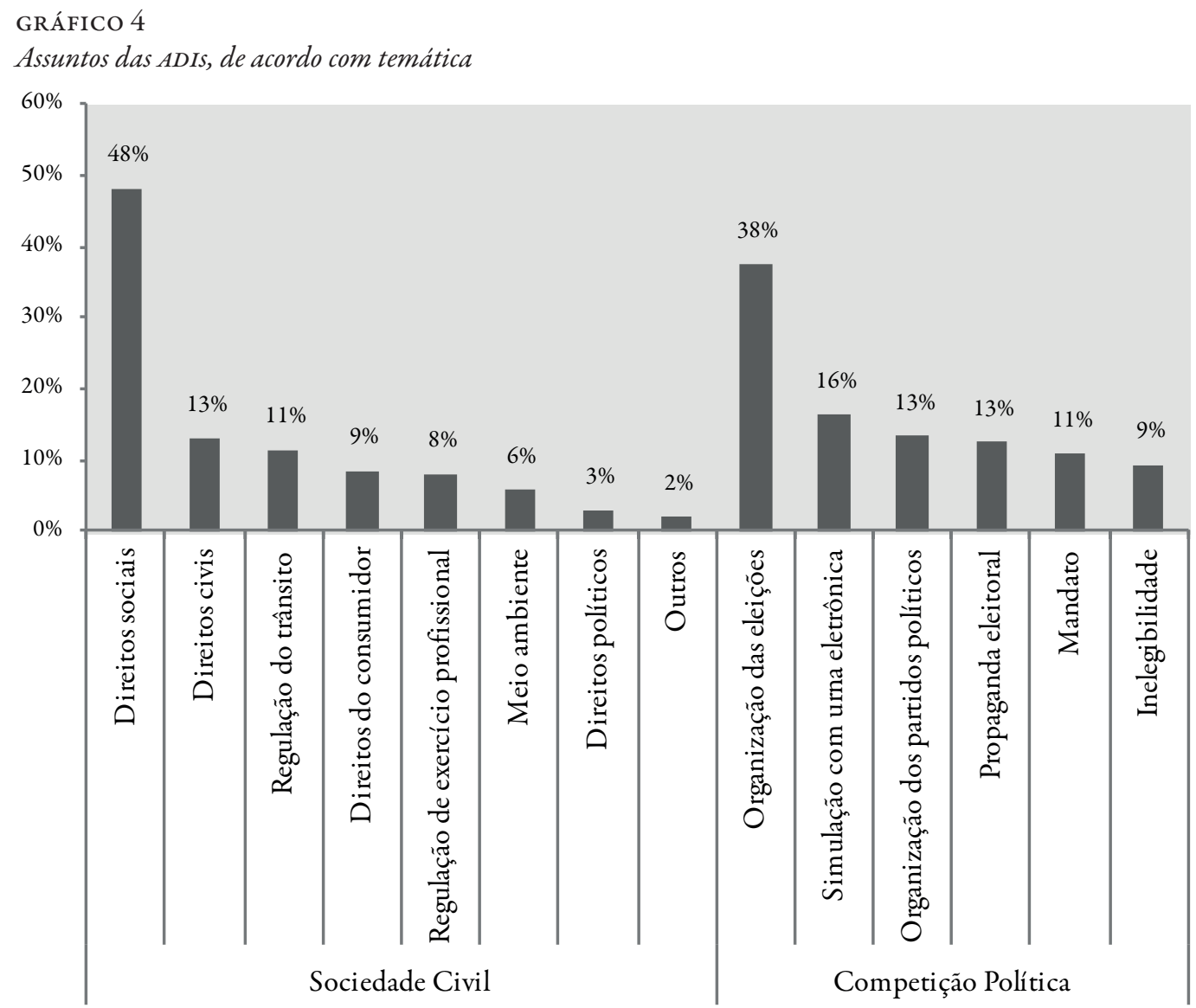

Base: ADIs com decisão final, julgadas de outubro de 1988 a julho de 2014: sociedade civil, 384; competição política, 128.

Vale lembrar que o STF aprovou a súmula vinculante n. 88, que proíbe o Judiciário de aumentar os vencimentos de servidores públicos com base na isonomia, vinculando juízes e tribunais a seguirem a diretriz do Supremo. Outra relevante discussão em curso é o auxílio-moradia aos juízes, membros do Ministério Público e da Defensoria - tudo isso deverá ser arbitrado pelo Supremo, que tem sido em sua atuação mais que um racionalizador da administração pública, um verdadeiro órgão de deliberação corporativa. Muito do que o Supremo faz é arbitrar interesses das profissões jurídicas, especialmente da magistratura - é notório que praticamente metade das questões do funcionalismo público decididas no âmbito da ADI tratem das próprias carreiras da justiça, incluindo os interesses da magistratura.

Um primeiro ponto que esses dados sucitam, portanto, é que, considerando os diversos papéis que a literatura atribui ao Supremo, encontramos, ao detalhar os assuntos peticionados, um papel pouco destacado: mais que uma ferramenta na gestão de conflitos entre os poderes Executivo e Legislativo, implementador de políticas 
controversas, instrumento de defesa de minorias (sua origem constitucional clássica) ou ainda recurso institucional estratégico de governo, o Supremo tem sido, com muita frequência, um eficaz órgão de deliberação corporativa.

É essa a instituição máxima de justiça que uma democracia precisa, ou seja, um tribunal que gira em torno do funcionamento do próprio Estado e das prerrogativas de seus servidores, em vez de atuar pela garantia de direitos ou influenciar em uma agenda de políticas públicas de alcance mais amplo? O colegiado de uma corte suprema deveria dedicar quase metade de seu tempo no controle de constitucionalidade para decidir sobre questóes relativas ao funcionalismo público? Parece-nos que não, e portanto temos um problema.

No entanto, o problema não é só do Supremo. Quem proporcionalmente levou mais frequentemente esse tipo de questão ao tribunal foi a Procuradoria-Geral da República (PGR), das quais $54 \%$ das ações decididas foram nessa temática, seguida dos governadores (46\%) e da OAB (44\%). As associações de classe (que incluem confederações e sindicatos), de quem seria esperado esse tipo de atuação, dado o requisito de pertinência temática, aparecem em quarto lugar, com 34\% do total de suas ações decididas tratando do funcionalismo público; os partidos políticos vêm em quinto. Mas a responsabilidade é também em parte do STF, quando este tem a prerrogativa de definir a pauta do dia (Gráfico 5).

É preocupante que instituições representativas como são os partidos políticos dediquem tanto esforço a essa temática - 30\% das ADIs julgadas requeridas por partidos políticos são referentes aos agentes públicos, sendo a temática mais expressiva de sua atuação no tribunal, seguida de questões de administração pública, com $22 \%$ do total de sua atuação.

Outra surpresa é a atuação da OAB. Uma instituição que ao longo da República erigiu uma imagem não apenas de órgão de fiscalização profissional, mas também de partícipe na construção da democracia brasileira, em defesa dos direitos humanos e do Estado Democrático de Direito, dedicar 44\% de sua atuação a questões ligadas ao funcionalismo público e outros $29 \%$ à administração da justiça é assumir um papel de defesa de interesses corporativos dos operadores do Direito - papel legítimo a um órgão de fiscalização e organização profissional, mas que não parece condizente com o papel mais amplo que a ordem reivindica para si e que o próprio Supremo reconhece, não exigindo dessa “associação" o requisito de pertinência temática.

Outro ponto importante na agenda do STF é a origem dos diplomas questionados. Do total de ADIs julgadas no período, $61 \%$ correspondem a diplomas de origem estadual, $28 \%$ de origem federal, $9 \%$ oriundos do Judiciário (decisões ou resoluções administrativas) e $2 \%$ têm outra origem, incluindo municípios, Ministério Público e conselhos profissionais. 
GRÁFICO 5

Temáticas das ADIs, de acordo com requerente

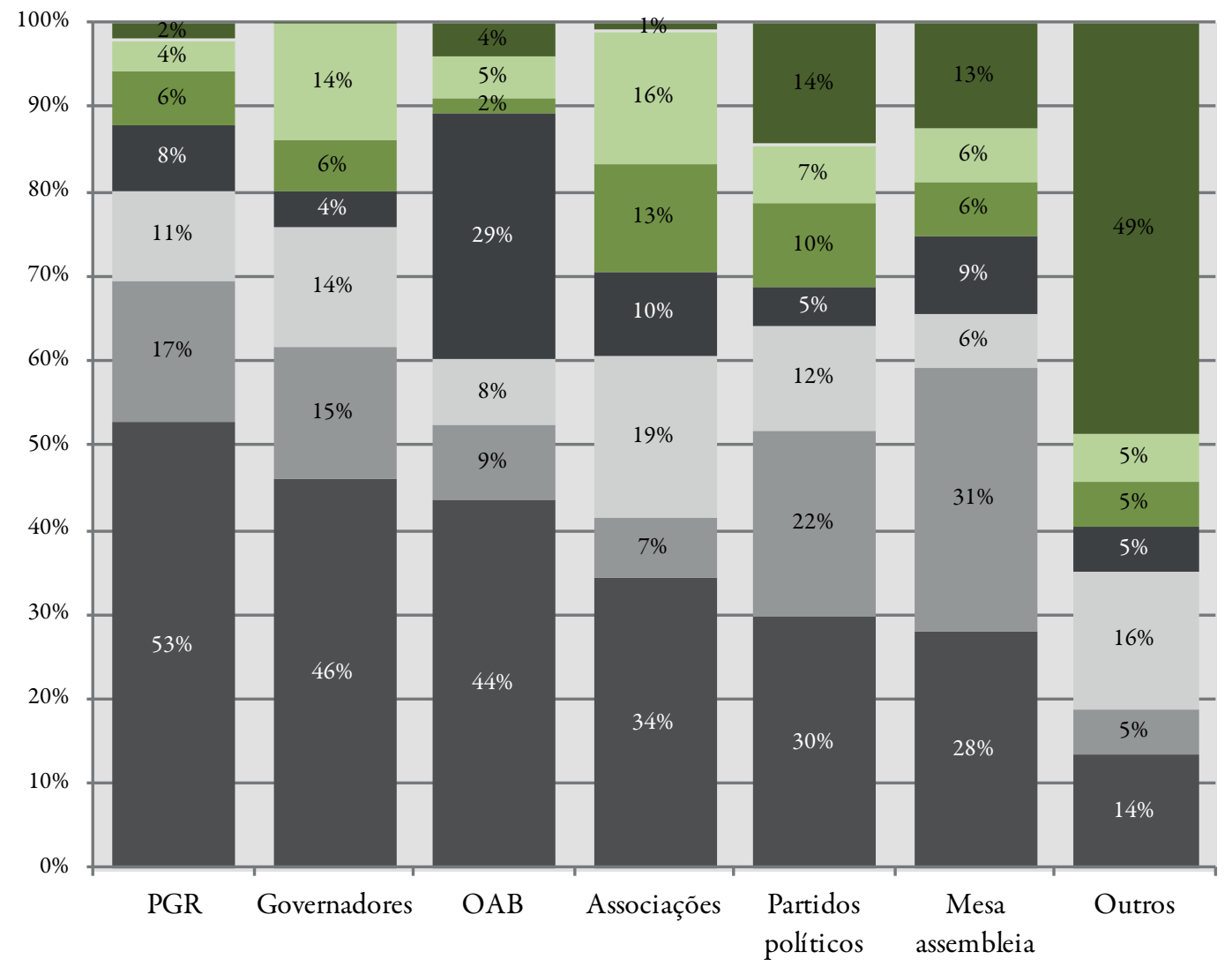

Agentes públicos Administração pública Sociedade civil

- Administração da justiça Regulação da economia $\square$ Política tributária

—Competição política

Base: ADIs com decisão final, julgadas de outubro de 1988 a julho de 2014: PGR, 538; governadores, 737; OAB, 103; associações, 688; partidos políticos, 577; mesa assembleia, 32; outros, 37

Notamos que nos diplomas federais há um maior equilíbrio entre as temáticas - os temas da sociedade civil têm praticamente a mesma incidência do tema agentes públicos, $22 \%$ e $23 \%$, respectivamente. Depois há destaque para regulação da economia e política fiscal e tributária e temas da administração pública (Gráfico 6).

Nos diplomas estaduais predominam questões do funcionalismo público (47\%), seguidos da administração pública e da sociedade civil. Nos diplomas do Judiciário, há destaque para o funcionalismo público, para a regulação da competição política (sobretudo questionamento das normativas do Supremo Tribunal Estadual - TSE) 
GRÁFICO 6

Temáticas das ADIs, de acordo com a origem do diploma questionado

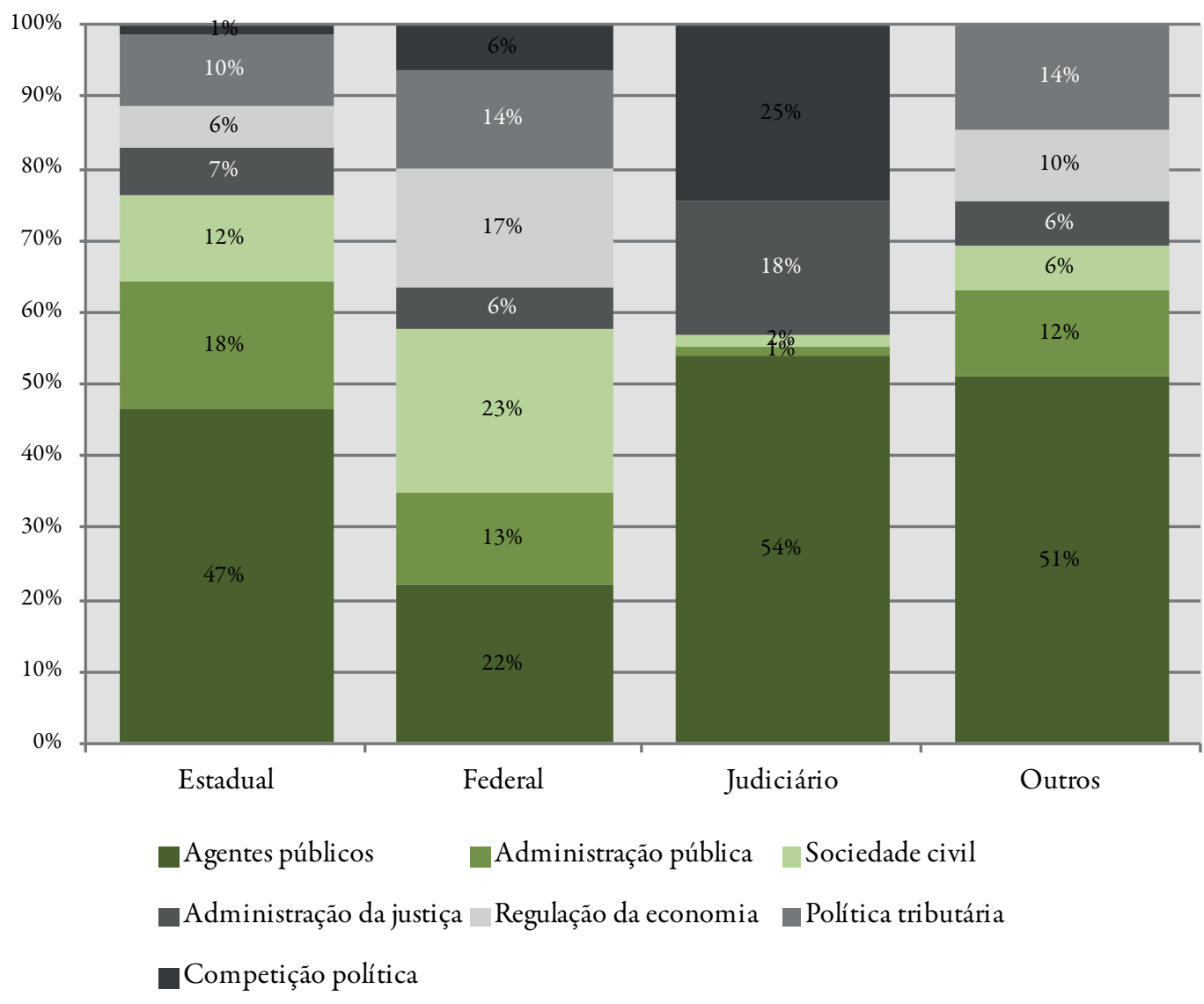

Base: ADIs com decisão final, julgadas de outubro de 1988 a julho de 2014: estadual, 1.638; federal, 785; judiciário, 240; outros, 49.

e administração da justiça. Nos demais diplomas, predominam as temáticas dos agentes públicos, com $51 \%$ do total.

É importante observar o processo decisório do STF. Como já pontuado, o tribunal decide muito monocraticamente, valendo-se dessa possibilidade como ferramenta de seletividade, sobretudo com base em critérios formais e quando há entendimento consolidado no Supremo para o não conhecimento de ações. Os casos que tratam de política tributária, da regulação da economia e da competição politica são os que o STF mais decide monocraticamente e, ao contrário, em termos de sociedade civil e agentes públicos, decide menos monocraticamente.

Considerando apenas as decisões do plenário (colegiado), vemos que o STF se comportou de forma bastante consensual, sendo que $71 \%$ do total de suas decisões no âmbito da ADI foram unânimes. Mas esse comportamento é bastante diversificado de 


\section{GRÁFICO 7}

Forma como ministros se agruparam para decidir o caso de acordo com temática

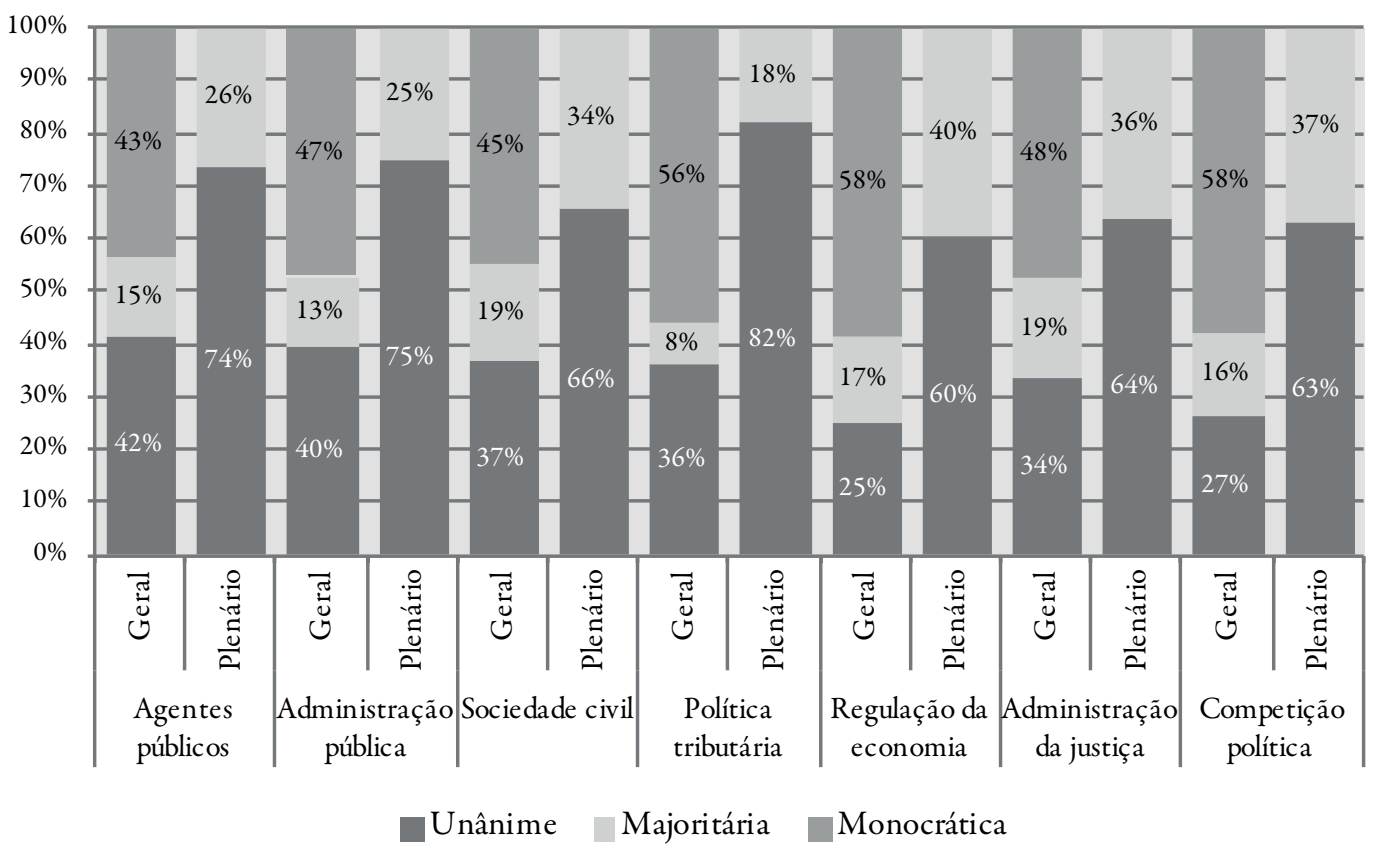

Base: ADIs, com decisão final, julgadas de outubro de 1988 a julho de 2014: agentes públicos, geral: 1.093, plenário: 617; administração pública: geral, 401, plenário, 212; sociedade civil: geral, 384, plenário, 213; política tributária: geral, 277, plenário, 122; regulação da economia: geral, 229, plenário, 96; administração da justiça: geral, 200, plenário, 105; competição política: geral, 128, plenário, 54.

acordo com a temática: os temas de política tributária e os de administração pública são os que mais produzem consenso entre os ministros. Já os que mais dividem o tribunal são a regulação da economia e a competição política, mas ainda assim mais da metade das decisões nessas duas temáticas foram unânimes (Gráfico 7).

Em termos do alcance das decisões e levando em conta apenas seu resultado final, é possível dizer que o STF interferiu bastante nas questões que julga: $62 \%$ das decisões colegiadas (plenário) resultaram em declarar total ou parcialmente a inconstitucionalidade do diploma em questão. Observando o total das decisões (geral, incluindo as monocráticas), o Supremo declarou total ou parcialmente procedente um terço das ações que julgou. Esses resultados não são nada desprezíveis, ainda mais quando consideramos com Kapiszewski e Taylor (2008) que:

[...] é inegável que governos frequentemente atuam constitucionalmente (o que implica que o endosso judicial de suas ações não pode ser equiparado com deferência ou subserviência). Além disso, as forças políticas da oposição frequentemente usam o Judiciário para contestar políticas governamentais perfeitamente legais e constitucionais, como uma extensão de 
suas estratégias políticas em outras partes do sistema político. Em terceiro lugar, mesmo os tribunais amplamente considerados independentes, decidem com mais frequência a favor do governo do que contra o governo. Por fim, os tribunais dependentes são perfeitamente capazes de desafiar seletivamente governos: por exemplo, mecanismos de seleção de casos (especialmente nos tribunais superiores) podem permitir que juízes decidam contrariamente ao governo em casos menos relevantes, inseridos no "intervalo de tolerância" dos poderes Executivo e Legislativo, evitando casos mais controversos (Kapiszewski e Taylor, 2008, p. 749).

Os temas mais acolhidos pelo STF, ou seja, aqueles em que o tribunal mais interveio declarando total ou parcialmente inconstitucionais os diplomas questionados, foram "agentes públicos" e "sociedade civil". Já “competição política” foi o menos acolhido, possivelmente pelo fato de muitas das ações serem questionamentos de decisões do TSE, que traz em sua composição ministros do próprio Supremo. É notório que, com exceção dessa temática e da política tributária, todas as demais têm como resultado em pelo menos metade dos casos a ingerência do Supremo, declarando a inconstitucionalidade total ou parcial dos diplomas, quando levamos em conta apenas as decisões do plenário (Gráfico 8).

GRÁFICO 8

Resultado da decisão, de acordo com temática

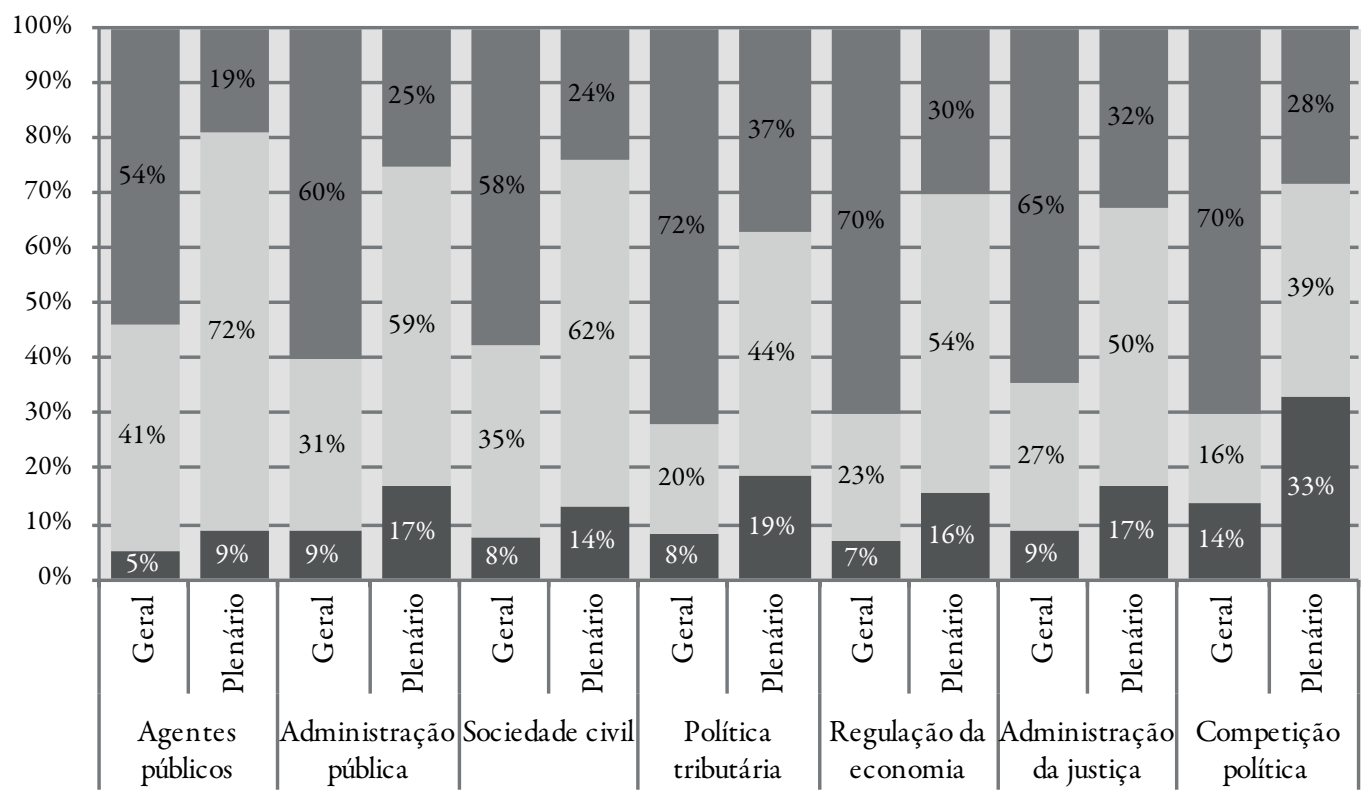

Improcedente $\quad$ Procedente (total/parte) Não conhecida/prejududica

Base: ADIs, com decisão final, julgadas de outubro de 1988 a julho de 2014: agentes públicos, geral: 1.093, plenário: 617; administração pública: geral, 401, plenário, 212; sociedade civil: geral, 384, plenário, 213; política tributária: geral, 277, plenário, 122; regulação da economia: geral, 229, plenário, 96; administração da justiça: geral, 200, plenário, 105; competição política: geral, 128, plenário, 54. 
GRÁFICO 9

Resultado da decisão, de acordo com origem do diploma

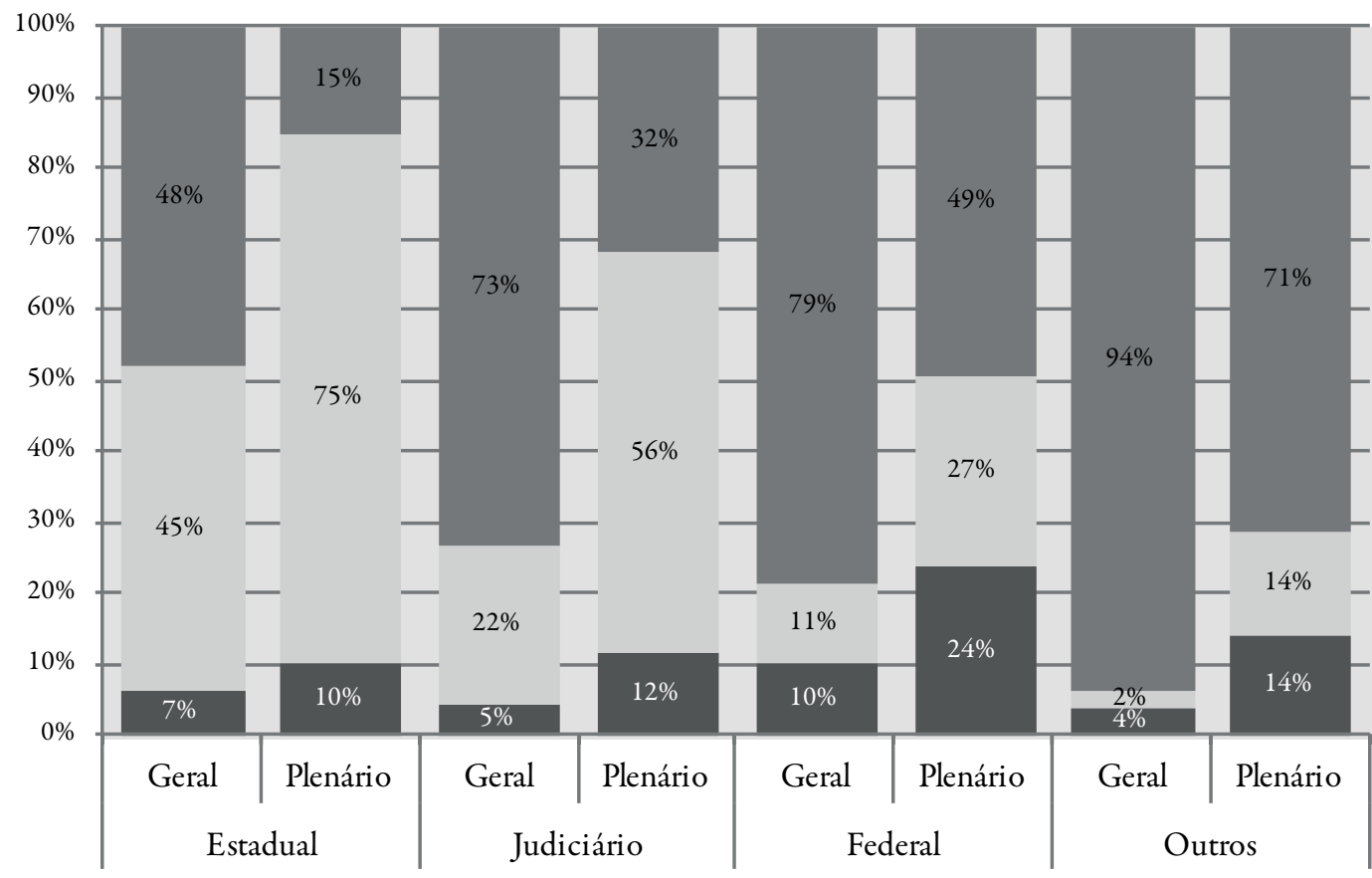

Improcedente Procedente (total/parte) Não conhecida/prejudicada

Base: ADIs, com decisão final, julgadas de outubro de 1988 a julho de 2014: estadual, geral: 1.638, plenário: 995; federal, geral: 785 , plenário: 323; judiciário, geral: 240, plenário: 94; outros, geral: 49, plenário: 7.

Com base nesses dados é possível afirmar que o Supremo interferiu consideravelmente na implementação de políticas públicas. Além disso, atuou como instância para a promoção e o avanço de uma agenda de direitos sociais, civis e coletivos, mas essa participação é ainda pequena, se comparada à sua atuação nas questões ligadas ao funcionalismo público.

Observando a origem do diploma, vemos que o STF interfere menos nas questões federais, mas, ainda assim, nas decisões colegiadas que tomou, o Supremo declarou total ou parcialmente a inconstitucionalidade de quase um terço de normas federais (Gráfico 9).

Outro ponto importante que toca no alcance das decisões é o tempo que o tribunal leva para julgar em definitivo uma questão. $\mathrm{O}$ tempo médio decorrido entre o ingresso das ações no tribunal e o seu julgamento final foi de 4,7 anos (1.706 dias), com mediana de três anos (1.114 dias), sendo que apenas $25 \%$ do total dessas ações 
foi decidida em até um ano. O tempo que o Supremo leva para julgar as ADIs fez com que mais da metade dos casos (62\%) fosse decidida em governo posterior ao governo em que deram entrada as ações. Entre as de mais longa duração em nossa base de dados está a ADI 73, uma das treze que levou 24 anos para ser decidida em definitivo, sendo negado seguimento à demanda - ou seja, a constitucionalidade de uma norma é questionada e o STF leva mais de duas décadas para se manifestar sobre a questão.

Considerando o tempo médio que o Supremo leva para decidir de acordo com a temática, temos que "agentes públicos" é a temática mais morosa, com duração média de 5,2 anos. Em segundo lugar está a administração pública e a administração da justiça, com 4,6 anos em média. A temática que o Supremo menos demora a se posicionar é a “regulação da competição política”, com 3,2 anos.

Apesar de o STF influenciar na implementação de políticas públicas, ele demorou a se posicionar. Alguns casos notórios da demora em decidir são os julgamentos envolvendo a exclusão do ICMS da base de cálculo do PIS/Cofins e a correção de cadernetas de poupança por perdas com planos econômicos. No caso específico de ADIs, ainda aguardam posicionamento do STF, por exemplo, a discussão sobre reconhecimento, delimitação e demarcação de terras quilombolas, na ADI 3.239 (datada de 25/6/2004) e o questionamento sobre a proibição de produção e comercialização do amianto, na ADI 3.357 (datada de 30/11/2004). Outro exemplo é a ADI 1.060 (de 28/4/1994), que teve liminar deferida, mas ainda aguarda julgamento do mérito, questionando lei que determina redução da carga horária semanal de servidor público do estado do Rio Grande do Sul que tenha filho dependente portador de deficiência (Gráfico 10).

Esses dados revelam que, para além da agenda temática, preocupa no processo decisório a demora do STF em decidir. E, mais ainda, a falta de explicitação dos critérios para decidir sobre o que decidir e quando decidir. Essa falta de critérios dá autonomia absoluta aos ministros para definirem a pauta de julgamentos dentre os temas judicializados. Esse poder está primeiro nas mãos do relator, que pode adiar o pedido de data de julgamento; depois, da presidência, que pode escolher não incluir um processo na pauta ou adiar sua inclusão; e nas mãos de cada ministro individualmente, que pode pedir vista no julgamento de uma ação, apesar de o regimento interno regulamentar o tempo de vista ${ }^{9}$ - na prática o STF não tem observado sua própria regra. Segundo

9. O Regimento Interno do Supremo Tribunal Federal, em seu artigo 134, estabelece que "[s]e algum dos ministros pedir vista dos autos, deverá apresentá-los para prosseguimento da votação, até a segunda sessão ordinária subsequente”. Além disso há a resolução 278/03, que regulamenta esse artigo do RISTD, modificada pela resolução 322/06, estabelecendo que se os autos não forem devolvidos no prazo fixado, "fica o pedido de vista prorrogado automaticamente por 10 (dez) dias, findos os quais a presidência do tribunal ou das turmas comunicará ao ministro o vencimento do referido prazo". 
GRÁFICO 10

Tempos da decisão, em anos, de acordo com temática

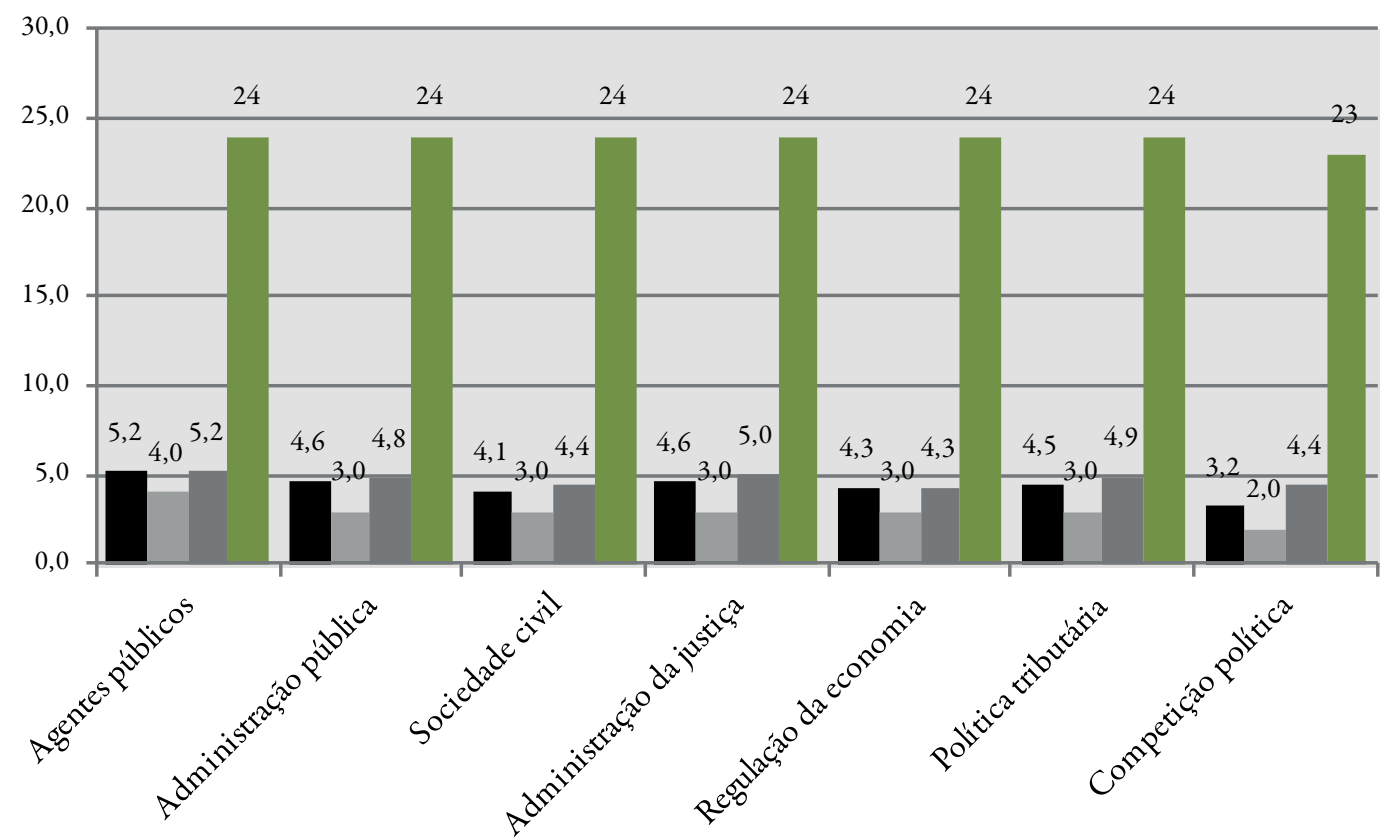

Média Mediana Desvio padrão Máximo

Base: ADIs, com decisão final, julgadas de outubro de 1988 a julho de 2014: agentes públicos: 1.093; administração pública: 401; sociedade civil: 384; política tributária: 277; regulação da economia: 229; administração da justiça: 200; competição política: 128.

Falcão et al. (2014), nas ADIs o pedido de vista dura em média 150 dias ${ }^{10}$. Toda essa discricionariedade dada ao STF leva o tribunal a concentrar bastante poder político.

"Supremo RH"

Dado que o funcionalismo público é tema dominante na pauta do Supremo em controle concentrado de constitucionalidade, com $40 \%$ das ADIs, convém detalhar os interesses em disputa nessas ações. Classificamos os interesses de acordo com a petição inicial, em três categorias: (1) combate a interesses corporativos, quando o autor da ação solicitava a declaração de inconstitucionalidade de uma norma que

10. Exemplo disso é a ADI 4.650, na qual a OAB questiona a constitucionalidade dos financiamentos de empresas privadas a partidos políticos e às campanhas eleitorais. Apesar de ter um placar de seis votos pela procedência da ação, desde 2/4/2014 o julgamento está parado devido ao pedido de vista do ministro Gilmar Mendes. E em declaração dada no início de 2015, o ministro sugere que seu voto estará pronto até o fim do ano (Cruvinel, 2015). 
ampliava prerrogativas das carreiras públicas; (2) defesa de interesses corporativos, quando o autor da ação solicitava a declaração de inconstitucionalidade de uma norma que restringia prerrogativas das carreiras públicas; e (3) regulação da atuação, quando a norma impugnada trazia mudanças na carreira ou atuação dos servidores, sem necessariamente ampliar ou restringir suas prerrogativas - aqui na maioria das vezes o pedido se justificava a partir do vício de iniciativa no processo legislativo.

As ADIs referentes aos agentes públicos buscaram o combate aos interesses corporativos das carreiras em $42 \%$ das vezes; em 36\%, a defesa desses interesses e em $22 \%$, a regulação da atuação.

Os governadores foram os campeões no questionamento de normas que ampliavam as prerrogativas do funcionalismo público, sobretudo as referentes aos aumentos de vencimentos e alteração nas regras para aposentadoria, sendo também comuns, em decorrência das constituições estaduais, questionamentos às promoções de servidores e à transformação de cargos públicos.

A Procuradoria-Geral da República vem em segundo lugar, com $47 \%$ da sua atuação na temática visando a restringir interesses corporativos - é notória a atuação da PGR questionando normas referentes à aposentadoria em cargos eletivos e à incorporação de adicionais por desempenho de cargos temporários ou de nomeação aos vencimentos integrais de servidores públicos que os desempenharam por um curto período de tempo (Gráfico 11).

Já as associações lideram a defesa de interesses corporativos, como esperado, vindo em segundo lugar os partidos políticos - metade das demandas dos partidos na temática "agentes públicos" visa à defesa de interesses corporativos do funcionalismo. A OAB tem na regulação da atuação sua principal demanda, seguida da defesa de interesses corporativos - o que reforça observação feita no início deste artigo, de que a Ordem comporta-se, em grande parte do seu esforço nas ADIs, tal qual uma associação de defesa de interesses de classe.

A fim de delinear os interesses em disputa nessas ADIs, subdividimos as categorias "defesa de interesses corporativos", "combate a interesses corporativos" e "regulação da atuação", de acordo com a carreira dos servidores em questão, separadas em três grupos: (1) magistratura; (2) demais carreiras da justiça (Ministério Público, Defensoria, Delegados da Polícia Civil); e (3) demais servidores. Essa opção de classificação persegue a verificação da hipótese de que o Supremo tem atuado como uma espécie de departamento de recursos humanos em grande parte de seu tempo (Tabela 1).

Vemos que $9 \%$ das ações visaram a defender interesses da magistratura e 9\%, interesses das demais carreiras da justiça. Outros $7 \%$ tiveram como alvo o combate aos interesses da magistratura e $11 \%$, o combate aos interesses corporativos das demais carreiras da justiça, o que totaliza $36 \%$ das ações na temática "agentes públicos”. 


\section{GRÁFICO 11}

Interesse expresso na petição inicial, de acordo com requerente

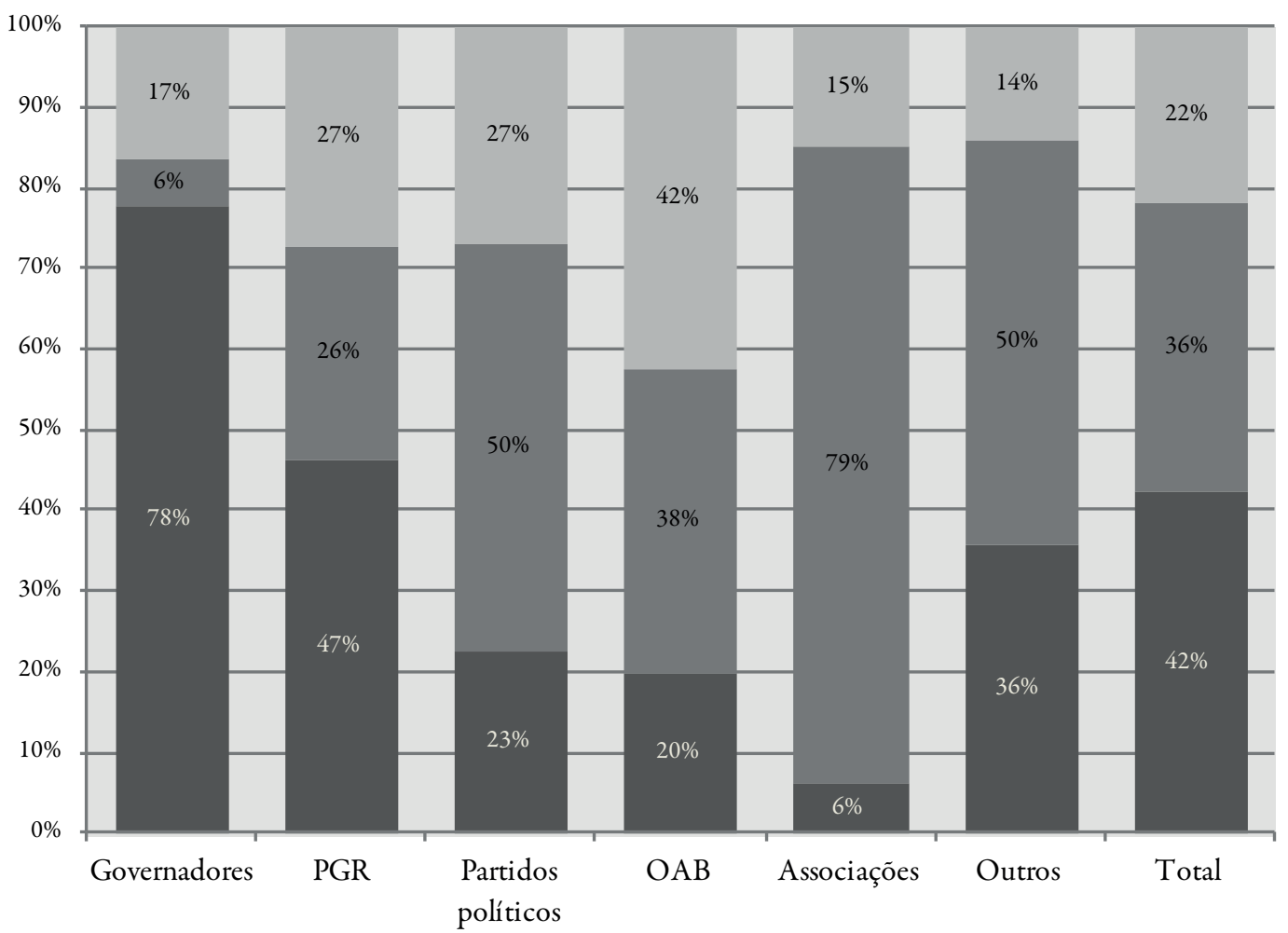

- Combate a interesses corporativos —Defesa de interesses corporativos Regulação de carreiras

Base: ADIs na temática agente público, com decisão final, julgadas de outubro de 1988 a julho de 2014: governadores, 341; PGR, 284; associações, 237; partidos políticos, 171; OAB, 45; outros, 15.

Somando a esse total $1 \%$ das ações que discutem aspectos da regulação da atuação da magistratura, $10 \%$ que tratam da regulação das demais carreiras da justiça e ainda os $0,3 \%$ das disputas internas da magistratura, temos que $47 \%$ do que o Supremo discute nessa temática é referente às próprias carreiras públicas da justiça, o que corresponde a cerca de um quinto do total de ADIs decididas pelo STF no período.

Mas como o Supremo respondeu a esses pedidos, ou seja, qual o alcance das decisões nessa temática? É possível afirmar que de maneira geral o tribunal colaborou mais para a redução dos interesses corporativos do que para a sua ampliação. Considerando o total de ADIs que buscavam combater interesses corporativos, o Supremo declarou total ou parcialmente procedente $48 \%$ - ou $77 \%$, excluindo as monocráticas. Já das ações que visavam a defender interesses corporativos, o tribunal julgou total ou parcialmente procedente $32 \%$ dos casos $-61 \%$ considerando apenas as ADIs julgadas no colegiado (Gráfico 12). 
Interesse expresso na petição inicial, de acordo com requerente

\begin{tabular}{l|c|c|c|c|c|c|c}
\hline & PGR & Governadores & Partidos políticos & Associaçães & OAB & Outros & Total \\
\hline $\begin{array}{l}\text { Combate a interesses corporativos } \\
\text { (demais carreiras públicas) }\end{array}$ & $16 \%$ & $58 \%$ & $10 \%$ & $4 \%$ & $16 \%$ & $21 \%$ & $25 \%$ \\
$\begin{array}{l}\text { Defesa de interesses corporativos } \\
\text { (demais carreiras públicas) }\end{array}$ & $7 \%$ & $4 \%$ & $47 \%$ & $30 \%$ & $24 \%$ & $36 \%$ & $18 \%$ \\
$\begin{array}{l}\text { Combate a interesses corporativos } \\
\text { (demais carreiras da justiça) }\end{array}$ & $14 \%$ & $15 \%$ & $11 \%$ & $2 \%$ & $4 \%$ & - & $11 \%$ \\
$\begin{array}{l}\text { Regulação de atuação } \\
\text { (demais carreiras públicas) }\end{array}$ & $11 \%$ & $10 \%$ & $19 \%$ & $5 \%$ & $7 \%$ & $7 \%$ & $10 \%$ \\
$\begin{array}{l}\text { Regulação de atuação } \\
\text { (demais carreiras da justiça) }\end{array}$ & $13 \%$ & $6 \%$ & $5 \%$ & $8 \%$ & $36 \%$ & $7 \%$ & $10 \%$ \\
$\begin{array}{l}\text { Defesa de interesses corporativos } \\
\text { (magistratura) }\end{array}$ & $10 \%$ & $1 \%$ & $1 \%$ & $25 \%$ & $2 \%$ & $14 \%$ & $9 \%$ \\
$\begin{array}{l}\text { Defesa de interesses corporativos } \\
\text { (demais carreiras da justiça) }\end{array}$ & $10 \%$ & $1 \%$ & $2 \%$ & $25 \%$ & $11 \%$ & $14 \%$ & $9 \%$ \\
$\begin{array}{l}\text { Combate a interesses corporativos } \\
\text { (magistratura) }\end{array}$ & $17 \%$ & $5 \%$ & $2 \%$ & $1 \%$ & - & - & $7 \%$ \\
$\begin{array}{l}\text { Regulação de atuação } \\
\text { (magistratura) }\end{array}$ & $4 \%$ & - & $2 \%$ & $0 \%$ & - & - & $1 \%$ \\
$\begin{array}{l}\text { Disputa interna (magistratura) } \\
\begin{array}{l}\text { Total (em números) } \\
\hline\end{array}\end{array}$ & - & - & 171 & 237 & 45 & 15 & 1093 \\
\hline
\end{tabular}

TABELA 2

Resultado da decisão, de acordo com o interesse expresso na petição inicial

\begin{tabular}{|c|c|c|c|c|c|c|}
\hline \multirow[b]{3}{*}{$\begin{array}{l}\text { Regulação de atuação } \\
\text { (demais carreiras da justiça) }\end{array}$} & \multicolumn{2}{|c|}{ Improcedente } & \multicolumn{2}{|c|}{$\begin{array}{l}\text { Procedente } \\
\text { (total/parte) }\end{array}$} & \multicolumn{2}{|c|}{$\begin{array}{l}\text { Não conhecida/ } \\
\text { prejudicada }\end{array}$} \\
\hline & Geral & Plenário & Geral & Plenário & Geral & Plenário \\
\hline & $7 \%$ & $10 \%$ & $51 \%$ & $84 \%$ & $43 \%$ & $7 \%$ \\
\hline $\begin{array}{l}\text { Combate a interesses corporativos } \\
\text { (demais carreiras públicas) }\end{array}$ & $4 \%$ & $6 \%$ & $52 \%$ & $79 \%$ & $44 \%$ & $15 \%$ \\
\hline $\begin{array}{l}\text { Regulação de atuação } \\
\text { (demais carreiras públicas) }\end{array}$ & $9 \%$ & $17 \%$ & $37 \%$ & $79 \%$ & $54 \%$ & $4 \%$ \\
\hline $\begin{array}{l}\text { Combate a interesses corporativos } \\
\text { (demais carreiras da justiça) }\end{array}$ & $9 \%$ & $14 \%$ & $45 \%$ & $78 \%$ & $47 \%$ & $8 \%$ \\
\hline $\begin{array}{l}\text { Defesa de interesses corporativos } \\
\text { (magistratura) }\end{array}$ & $4 \%$ & $8 \%$ & $42 \%$ & $74 \%$ & $53 \%$ & $19 \%$ \\
\hline $\begin{array}{l}\text { Combate a interesses corporativos } \\
\text { (magistratura) }\end{array}$ & $6 \%$ & $10 \%$ & $36 \%$ & $67 \%$ & $58 \%$ & $23 \%$ \\
\hline $\begin{array}{l}\text { Defesa de interesses corporativos } \\
\text { (demais carreiras da justiça) }\end{array}$ & $2 \%$ & $4 \%$ & $38 \%$ & $66 \%$ & $60 \%$ & $31 \%$ \\
\hline $\begin{array}{l}\text { Defesa de interesses corporativos } \\
\text { (demais carreiras públicas) }\end{array}$ & $5 \%$ & $10 \%$ & $25 \%$ & $52 \%$ & $70 \%$ & $38 \%$ \\
\hline $\begin{array}{l}\text { Regulação de atuação } \\
\text { (magistratura) }\end{array}$ & - & - & $27 \%$ & $50 \%$ & $73 \%$ & $50 \%$ \\
\hline $\begin{array}{l}\text { Disputa interna } \\
\text { (magistratura) }\end{array}$ & - & - & - & - & $100 \%$ & - \\
\hline Total & $5 \%$ & $9 \%$ & $41 \%$ & $72 \%$ & $54 \%$ & $19 \%$ \\
\hline
\end{tabular}


GRÁFICO 12

Resultado da decisão, de acordo com o interesse expresso na petição inicial

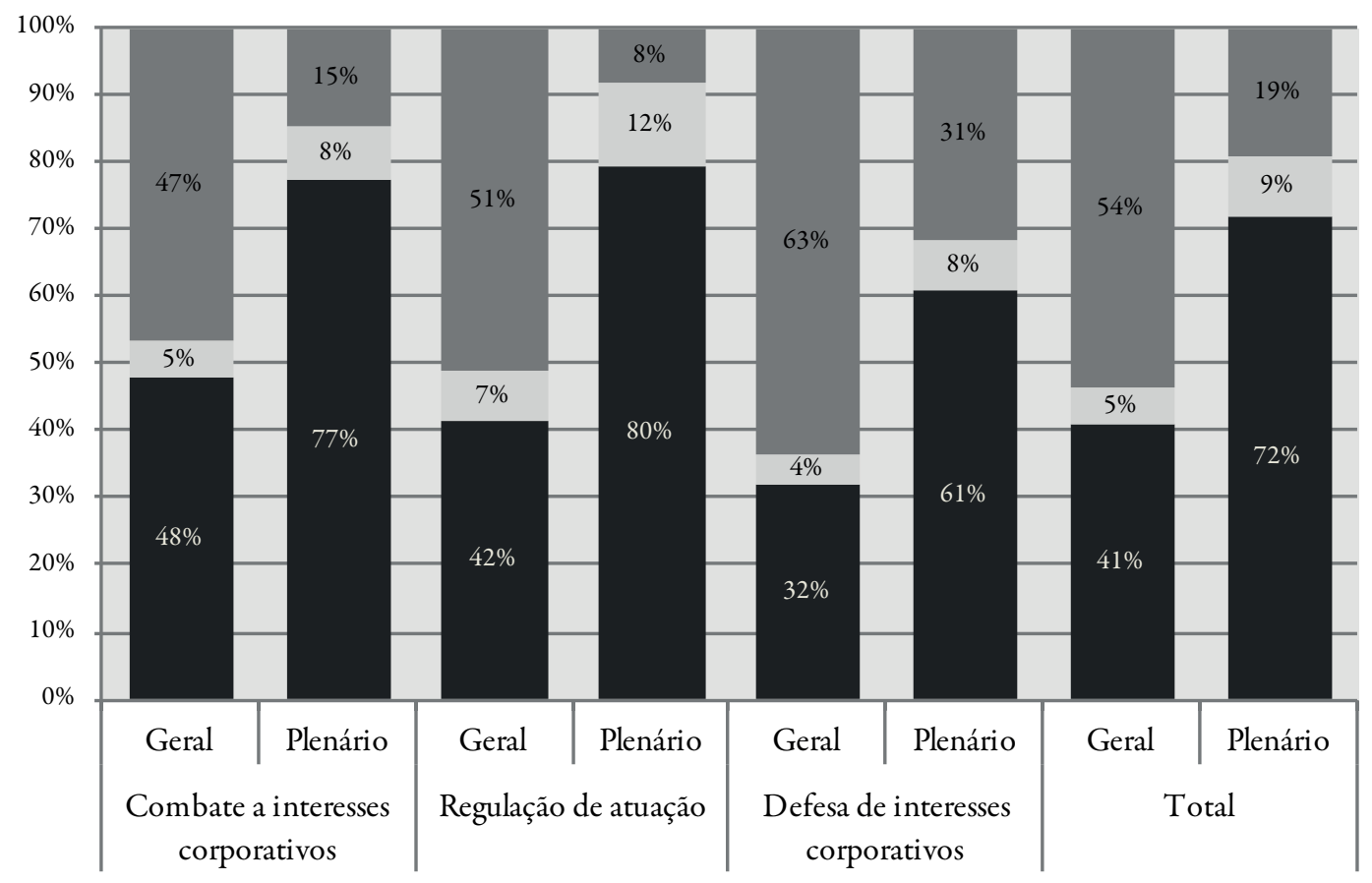

Procedente (total/parte) Improcedente Não conhecida/prejudicada

Base: ADIs na temática agente público, com decisão final, julgadas de outubro de 1988 a julho de 2014: combate a interesses corporativos: geral, 465, plenário, 288; defesa de interesses corporativos: geral, 391, plenário, 207; regulação de atuação: geral, 237, plenário, 122.

Observando os interesses específicos em disputa, notamos que o Supremo foi mais ativo em combater os interesses de outras carreiras públicas que não as da justiça - julgou total ou parcialmente procedente $52 \%$ das ações que combatiam interesses corporativos das demais carreiras públicas, $45 \%$ das ações que combatiam interesses das demais carreiras da justiça e 36\% das ações que combatiam interesses da magistratura (Tabela 2).

Entre as ações que defendiam interesses corporativos, o STF julgou procedente, no todo ou em parte, $42 \%$ das ações que defendiam interesses da magistratura, 38\% das ações que defendiam os interesses das demais carreiras da justiça e $25 \%$ das ações que defendiam interesses das demais carreiras públicas. Em termos da regulação da atuação das carreiras, aquelas que se referiam à magistratura foram as em que menos o STF interveio - apenas $27 \%$ dessas ações foram julgadas procedentes.

Esses dados reforçam a constatação de que o Supremo Tribunal Federal desempenhou o papel de eficaz órgão de deliberação corporativa. 


\section{Conclusão}

Buscamos neste artigo mapear o conteúdo da agenda decisória do STF e o alcance de suas decisóes no controle concentrado de constitucionalidade das leis, com base nas ADIs julgadas pelo tribunal entre os anos de 1988 e 2014. A partir daí, discutimos os papéis que o STF desempenhou ao arbitrar interesses em disputa no processo de revisão judicial.

O Supremo investiu 40\% do seu tempo no âmbito da ADI em assuntos ligados ao funcionalismo público, sendo que aproximadamente $20 \%$ das ações trataram exclusivamente das carreiras públicas jurídicas. Em segundo lugar, estão assuntos ligados à administração pública, com 15\% do total de ações, e em terceiro, temas ligados à agenda de direitos civis, sociais, políticos e coletivos (que somam 12\% do total das ADIs), que juntamente com outros temas que tratam da relação entre particulares, somam 14\% do total de ADIs. À administração da justiça, o Supremo dedicou 7\% do seu tempo em ADIs. Com isso, mais de um quarto da agenda do STF no controle concentrado de constitucionalidade foi dedicada à regulação das carreiras públicas jurídicas e à administração das instituições estatais de justiça.

Portanto, observando os interesses que dominaram a agenda decisória do Supremo, podemos afirmar que quando se fala em judicialização da política no Brasil, no que se refere à atuação do Supremo Tribunal Federal, mais do que papel de mediador de disputas entre diferentes órgãos do governo, de instância de implementação de direitos sociais e coletivos ou ainda instituição contramajoritária, o tribunal desempenhou o papel de instituição de deliberação corporativa.

O sTF tem, sim, permitido em alguma medida a incorporação de vozes minoritárias no processo político, mas seu papel predominante foi o de propiciar aos governos, às associações de classe e às próprias instituições de justiça (sobretudo via Procuradoria-Geral da República) um espaço privilegiado de interferência na implementação de políticas públicas ligadas à regulação das burocracias do Estado e suas prerrogativas.

Qual o impacto da atuação de um tribunal com essa agenda decisória para a democracia? Trazemos aqui a ponderação de Hirschl (2013) de que quando os políticos eleitos abstêm-se de lidar com um desafio de política pública, a intervenção judicial pode ser um caminho para "abrir o debate sobre o assunto". Mas quando o autor observa os impactos efetivos da revisão judicial sobre uma agenda de avanço e garantia de direitos, conclui que são muito pouco significativos no que se refere aos direitos positivos e coletivos (trabalho, educação, saúde, moradia, entre outros), tendo uma efetividade um pouco maior para os direitos negativos (restrições à ação do Estado, impedindo-o de interferir nas atividades econômicas e na vida privada, como a liberdade de expressão, o devido processo legal, a igualdade formal). 
Pensando o caso brasileiro a partir dessa ponderação, observamos que a demanda proporcionalmente mais acolhida pelo Supremo, ou seja, aquela em que ele mais tem interferido, declarando a inconstitucionalidade total ou parcial da norma em questão, é a relativa aos agentes públicos - primeiro para restringir prerrogativas e depois para ampliá-las ou garanti-las. Em segundo lugar, vêm as demandas ligadas à sociedade civil, sendo a "regulação do trânsito" o assunto que o tribunal mais interveio, declarando procedentes $66 \%$ das ações que julgou nessa temática. Depois, as ações que tratam dos direitos civis, julgando total ou parcialmente procedentes $38 \%$ dessas ações. Já em termos de direitos sociais, o STF interveio em 30\% dos casos.

O tribunal foi muito mais interventivo quando tratava da burocracia do Estado ou mesmo quando decidia acerca de direitos negativos se comparado às suas decisões relativas aos direitos positivos e coletivos. Porém, ainda que a intervenção do Supremo nessa área seja menor, ela tem sido significativa não só para "abrir a agenda de debates sobre o assunto", como também para influenciar a agenda de implementação de poucas, mas relevantes, políticas públicas, como a implementação do sistema de cotas em universidades. Na arena de conflitos políticos, o papel do Supremo, apesar de pontual, também pode ser considerado significativo, sendo exemplos os casos da declaração de constitucionalidade da perda de mandato eletivo por infidelidade partidária e da Lei da Ficha Limpa.

O Supremo é órgão essencial para a governança democrática, portanto não deve dispender tanto tempo arbitrando interesses e conflitos da burocracia do Estado, e sim dedicar-se às questões de maior relevo e importância nas arenas social e política do país.

\section{Referências Bibliográficas}

Arantes, Rogério Bastos. (1997), Judiciário e politica no Brasil. São Paulo, Idec/Sumaré/ Fapesp/Educ.

Brasil. Lei 9.868, de 10 de novembro de 1999. Dispõe sobre o processo e julgamento da ação direta de inconstitucionalidade e da ação declaratória de constitucionalidade perante o Supremo Tribunal Federal. Disponível em http://www.planalto.gov.br/ccivil_03/leis/ L9868.htm, consultado em 8/12/2015.

. Supremo Tribunal Federal (STF). Regimento interno. Atualizado até setembro de 2015, consolidado e atualizado até maio de 2002 por Eugênia Vitória Ribas. Brasília: STF, 2015. Disponível em http://www.stf.jus.br/arquivo/cms/legislacaoRegimentoInterno/anexo/ RISTF_Setembro_2015_versao_eletronica.pdf, consultado em 8/12/2015.

Carvalho, Ernani Rodrigues de. (2004), "Em busca da judicialização da política no Brasil: apontamentos para uma nova abordagem”. Revista de Sociologia e Politica, 23: 115-126. 
. (2009), "Judicialização da política no Brasil: controle de constitucionalidade e racionalidade política”. Análise Social, 191 (44): 315-335.

CAStro, Marcos Faro de. (1997), "O Supremo Tribunal Federal e a judicialização da política”. Revista Brasileira de Ciências Sociais, 12 (34): 147-156.

Cruvinel, Tereza. (2015), “Gilmar não libera tão cedo...”. Blog Tereza Cruvinel, 5/1. Disponível em http://terezacruvinel.com/2015/01/05/gilmar-nao-libera-tao-cedo, consultado em 7/1/2015.

Domingo, Pilar. (2004), "Judicialization of politics or politicization of the Judiciary? Recent trends in Latin America”. Democratization, 1(11): 104-126.

. (2010), "Novel appropriations of the law in the pursuit of political and social change". In: Couso, Javier et al. (orgs.). Cultures of legality: judicialization and political activism in Latin America. Cambridge, Cambridge University Press, pp. 254-278.

Engelmann, Fabiano \& Cunha Filho, Marcio C. (2013), "Ações judiciais, conteúdos políticos: uma proposta de análise para o caso brasileiro". Revista de Sociologia e Politica, 45 (21): 57-72.

FALCão, Joaquim. (2014), "Supremo, servidores públicos e magistrados". Blog Jota, 9/10. Disponível em http://jota.info/materias75-supremo-servidores-publicos-e-magistrados, consultado em 20/12/2014.

FalCão, Joaquim et al. (2011), "O Supremo Tribunal Federal processual”. In: Martins, Ives Gandra da Silva et al. (orgs.). Estudos: direito público. São Paulo, Lex Magister, pp. 299-308. . (2014), "III Relatório Supremo em números: o Supremo e o tempo". Rio de Janeiro, Escola de Direito do Rio de Janeiro da Fundação Getulio Vargas. Disponível em http:// bibliotecadigital.fgv.br/dspace/handle/10438/12055, consultado em 20/12/2014.

FAlCÃo, Joaquim \& Oliveira, Fabiana Luci de. (2013), "O stF e a agenda pública nacional: de outro desconhecido a supremo protagonista?". Lua Nova, 88: 429-469

HIRSCHL, Ran. (2007), Towards juristocracy: the origins and consequences of the new constitutionalism. Cambridge, Harvard University Press.

(2013), "Epilogue: courts and democracy between ideals and realities". Representation, 3 (49): 361-373.

Kapiszewski, Diana \& TaYlor, Matthew M. (2008). “Doing courts justice? Studying judicial politics in Latin America”. Perspectives on Politics, 4 (6): 741-767.

Koerner, Andrei. (2013). "Ativismo judicial? Jurisprudência constitucional e política no STF pós-88”. Novos Estudos Cebrap, 96: 69-85.

et al. (2011), "Sobre o judiciário e a judicialização". Nuevos Paradigmas de las Ciencias Sociales Latinoamericanas, 4 (2): 17-52.

Macedo, Fausto. (2014), “Imenso varejo de miudezas' toma Supremo, diz Barroso”. Estadão, 26/8. Disponível em http://politica.estadao.com.br/blogs/fausto-macedo/imenso-varejo-de-miudezas-toma-supremo-diz-barroso, consultado em 20/12/2014.

Maciel, Débora Alves \& Koerner, Andrei. (2002), “Sentidos da judicialização da política: duas análises". Lua Nova, 57: 113-133. 
Oliveira, Eduardo Santos de. (2013), “O sistema político brasileiro hoje: o governo do Supremo Tribunal Federal e legitimidade democrática”. Sociologias, 33: 206-246.

Oliveira, Fabiana Luci de. (2011), Justiça, profissionalismo e politica: o sTF e o controle de constitucionalidade das leis no Brasil. Rio de Janeiro, Editora FGV.

. (2013), "Supremo relator: processo decisório e mudanças na composição do STF nos governos FHC e Lula”. Revista Brasileira de Ciências Sociais, 80 (27): 89-115.

Oliveira, Vanessa Elias. (2005), “Judiciário e privatizações no Brasil: existe uma judicialização da política?". Dados, 3 (48): 559-587.

SADEK, Maria Tereza Aina. (2011), “O Judiciário e a arena pública”. In: Sola, Lourdes \& Loureiro, Maria Rita. Democracia, mercado e Estado: o B de Brics. Rio de Janeiro, Editora FGV, pp. 121-147.

Sundfeld, Carlos Ari et al. (2010), Controle de constitucionalidade e judicialização: o STF frente à sociedade e aos Poderes. Belo Horizonte, Faculdade de Filosofia e Ciências Humanas. Disponível em: http://democraciaejustica.org/cienciapolitica3/sites/default/files/controle_de_constitucionalidade_e_judicializacao.pdf, consultado em 20/12/2014.

TAYLOR, Matthew. (2007), “O Judiciário e as políticas públicas no Brasil”. Dados, 2 (50): 229-257. . (2008), Judging policy: courts and policy reform in democratic Brazil. Stanford, Stanford University Press.

TATE, C. Neal. (1995). “Why the expansion of judicial power?”. In: VALLINDER, Torbjörn \& . The global expansion of judicial power: the judicialization of politics. Nova York, New York University Press, pp. 27-37

VALLINDER, Torbjörn. (1995), “When the courts go marching in”. In: \& TATE, C.

Neal. The global expansion of judicial power: the judicialization of politics. Nova York, New York University Press, pp. 13-26.

Vieira, Oscar Vilhena. (1994), Supremo Tribunal Federal: jurisprudência política. São Paulo, Revista dos Tribunais. . (2008), "Supremocracia”. Revista Direito GV, 4 (2): 441-464.

WANG, Daniel Wei Liang. (2009), Poder Judiciário e participação democrática nas políticas públicas de saúde. São Paulo, dissertação de mestrado, Faculdade de Direito da Universidade de São Paulo. Disponível em http://www.teses.usp.br/teses/disponiveis/2/2134/tde-21062011134507, consultado em 29/12/2014.

WERneCK VIANna, Luiz et al. (1999), A judicialização da politica e das relaçôes sociais no Brasil. Rio de Janeiro, Revan. (2007), "Dezessete anos de judicialização da política”. Tempo Social, 2 (19): 39-85.

\section{Resumo}

Agenda suprema: interesses em disputa no controle de constitucionalidade das leis no Brasil Neste artigo discutimos os papéis que o Supremo Tribunal Federal (STF) têm desempenhado ao arbitrar interesses em disputa no controle de constitucionalidade das leis, via ações direitas de 
inconstitucionalidade (ADIS). Para isso, baseamo-nos na análise quantitativa das ADIs julgadas pelo tribunal entre os anos de 1988 e 2014, mapeando o conteúdo de sua agenda decisória, verificando em que medida o Supremo tem feito diferença nas arenas de conflito social e político do país. Concluímos que apesar do Supremo arbitrar importantes disputas sociais e políticas, sua agenda tem sido tomada por uma pauta ligada ao delineamento das carreiras públicas, decidindo sobre expansão ou contenção das prerrogativas da burocracia do Estado. Entre os diversos papéis que a literatura corrente acerca da judicialização da política tem atribuído às supremas cortes ao redor do mundo, em um cenário de expansão do poder político do Judiciário, verificamos que, no caso do Brasil, mais do que instituição contramajoritária ou instância de implementação de direitos sociais e coletivos, o STF tem desempenhado papel de verdadeiro órgão de deliberação corporativa.

Palavras-chave: Supremo Tribunal Federal; Agenda decisória; Controle de constitucionalidade; Judicialização da política; Funcionalismo público.

\section{Abstract}

Supreme agenda: interests in dispute in judicial review in Brazil

In this paper we discuss the roles that Brazil's Supreme Court (STF) has played while arbitrating interests in dispute in the constitutionality control of laws, through judicial review cases (ADIs). For this, we rely on quantitative analysis of ADIs judged by the court between the years 1988 and 2014, mapping the content of the Court's decision-making agenda and the scope of its decisions, determining to what extent the Supreme Court has made a difference in arenas of social and political conflict in the country. We conclude that despite taking part in important disputes in arenas of social and political conflict, Supreme Court's agenda has been taken by issues related to the delineation of public careers, deciding on expansion or restraint of state bureaucracy prerogatives. Among the different roles that the current literature on judicialization of politics has attributed to Supreme Courts around the world, in a scenario of expanding political power of the judiciary, we found out that in Brazil, more than a countermajoritarian institution, or an instance to advance social and collective rights, Supreme Court has played the role of a true corporate deliberation body.

Keywords: Supreme Court; Decision-making agenda; Judicial review; Judicialization of politics; Civil servants.

Texto recebido em 8/1/2015 e aprovado em 24/3/2015. DoI:10.11606/0103-2070. ts.2016.106021.

Fabiana Luci Oliveira é professora do Departamento de Sociologia e do Programa de Pós-graduação em Sociologia da Universidade Federal de São Carlos (UFSCar) e bolsista de produtividade do CNPq. E-mail: : fabianaluci@gmail.com. 